\title{
PIIISGUC.ORG
}

"iş, GÜÇ" ENDÜSTRi iLişKILERI VE INSAN KAYNAKLARI DERGISi

"IS, GUC" INDUSTRIAL RELATIONS AND HUMAN RESOURCES JOURNAL

\section{Akademiden Teknokrasiye, Teknokrasiden Bürokrasiye Türkiye'de Yetişkinlere Yönelik Sosyal Politika Eğitimlerinin Yönetimi Üzerine Bir İnceleme ve Yeni Bir Model Önerisi}

\section{Dr. Erdem CAM}

Çalışma ve Sosyal Güvenlik Eğitim ve Araştırma Merkezi

Nisan/April 2013, Cilt/Vol.: 15, Sayı/Num.: 2, Sayfa/Page: 29-51

ISSN: 1303-2860, DOI: 10.4026/1303-2860.2013.0224.x

Makalenin çevrimiçi kopyasına erişmek için / To reach the online copy of the article:

http://www.isguc.org/index.php?p=article\&id=509\&cilt=15\&sayi=2\&yil=2013

Makale İçin İletişim/Correspondence to:

Dr. Erdem Cam, e-mail: erdemcam@yahoo.com 


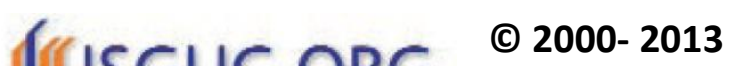 \\ "İş,Güç" Endüstri ilişkileri ve İnsan Kaynakları Dergisi "Işs,Güç" Industrial Relations and Human Resources Journal
}

\author{
Nisan/April 2013, Cilt/Vol: 15, Say1/Num: 2, \\ Sayfa/Page: 29-51, DOI: 10.4026/1303-2860.2013.0224.x
}

"İş,Güç" Endüstri İlişkileri ve İnsan Kaynakları Dergisi, yılda dört kez yayınlanan hakemli, bilimsel elektronik dergidir. Çalışma hayatına ilişkin makalelere yer verilen derginin temel amact; belirlenen alanda akademik gelişime ve paylaşıma katkıda bulunmaktır.

"İş,Güç" Endüstri İlişkileri ve İnsan Kaynakları Dergisi'nde, 'Türkçe' ve 'İngilizce' olarak iki dilde makale yayınlanmaktadır. "İş,Güç" Endüstri İlişkileri ve İnsan Kaynakları Dergisi, ulusal ve uluslararası birçok indekste taranmaktadır. (Cabell's Directories, Ebsco Socindex, Index Islamicus, Index Copernicus International, Worldwide Political Science Abstracts, Sociological Abstract, Ulakbim Sosyal Bilimler Veritabanı, ASOS Index)

Editör / Editor in Chief

Aşkın Keser (Uludağ University)

\section{Editör Yardımcıları / Co-Editors}

Şenol Baştürk (Uludăg University)

K.Ahmet Sevimli (Uludağ University)

Gözde Yllmaz (Marmara University)

Uygulama / Design

Yusuf Budak (Kocaeli University)

Tarandiğı Indeksler / Indexes ASOS INDEX

CABELL'S DIRECTORIES

EBSCO SOCINDEX

Index ISLAMICUS

Index COPERNICUS Int.

Sociological Abstract

ULAKBİM Sosyal Bilimler

Veritanı

Worldwide Political Science

Abstracts

\author{
Yayın Kurulu / Editorial Board \\ Dr.Şenol Baştürk (Uludă̆ University) \\ Yrd.Doç.Dr.Zerrin Fırat (Uludă̆ University) \\ Doç.Dr.Aşkın Keser (Uludă̆ University) \\ Prof.Dr.Ahmet Selamoğlu (Kocaeli University) \\ Yrd.Doç.Dr.Ahmet Sevimli (Uludağ University) \\ Doç.Dr.Abdulkadir Şenkal (Kocaeli University) \\ Doç.Dr.Gözde Yılmaz (Marmara University) \\ Yrd.Doç.Dr.Memet Zencirkıran (Uludă̆ University)
}

Uluslararası Danışma Kurulu / International Advisory Board

Prof.Dr.Ronald Burke (York University - Kanada)

Assoc.Prof.Dr.Glenn Dawes (James Cook University - Avustralya)

Prof.Dr.Jan Dul (Erasmus University - Hollanda)

Prof.Dr.Alev Efendioğlu (University of San Francisco - ABD)

Prof.Dr.Adrian Furnham (University College London - Ingiltere)

Prof.Dr.Alan Geare (University of Otago - Yeni Zellanda)

Assoc. Prof. Dr. Diana Lipinskiene (Kaunos University - Litvanya)

Prof.Dr.George Manning (Northern Kentucky University - ABD)

Prof.Dr.Mustafa Özbilgin (Brunel University - UK)

Assoc. Prof. Owen Stanley (James Cook University - Avustralya)

Prof.Dr.Işık Urla Zeytinoğlu (McMaster University - Kanada)

Ulusal Danışma Kurulu / National Advisory Board

Prof.Dr.Yusuf Alper (Uludă̆ University)

Prof.Dr.Veysel Bozkurt (İstanbul University)

Prof.Dr.Toker Dereli (Işık University)

Prof.Dr.Nihat Erdoğmuş (İstanbul Şehir University)

Prof.Dr.Ahmet Makal (Ankara University)

Prof.Dr.Süleyman Özdemir (İstanbul University)

Prof.Dr.Ahmet Selamoğlu (Kocaeli University)

Prof.Dr.Nadir Suğur (Anadolu University)

Prof.Dr.Nursel Telman (Maltepe University)

Prof.Dr.Cavide Uyargil (Istanbul University)

Prof.Dr.Engin Yildırım (Anayasa Mahkemesi)

Doç.Dr.Arzu Wasti (Sabancı University)

Dergide yayınlanan yazllardaki görüşler ve bu konudaki sorumluluk yazarlarına aittir.

Yayınlanan eserlerde yer alan tüm içerik kaynak gösterilmeden kullanılamaz.

All the opinions written in articles are under responsibilities of the authors.

The published contents in the articles cannot be used without being cited. 


\title{
Akademiden Teknokrasiye, Teknokrasiden Bürokrasiye Türkiye'de Yetişkinlere Yönelik Sosyal Politika Eğitimlerinin Yönetimi Üzerine Bir İnceleme ve Yeni Bir Model Önerisi ${ }^{1}$
}

\author{
Dr. Erdem CAM \\ Çalışma ve Sosyal Güvenlik Eğitim ve Araştırma Merkezi
}

\begin{abstract}
An Analysis on Administration of Social Policy Trainings, Academy to Technocracy Technocracy to Bureaucracy, in Turkey and a New Model Proposal
\end{abstract}

\begin{abstract}
Social policy trainings which are implemented for adults organize by Ministry of Labour's in many countries. This responsible organization for this purpose is Centre for Labour and Social Security Training and Research in Turkey. In this study, the training and research activities of the Centre are discussed in the context of labour administration. Through the analyses on the institution, it is identified that legislative changes and reformation on the structure of the Centre should be conducted in order to achieve the objectives and tasks effectively that are mentioned in the institutional act of the Centre and social policy perspective. For this purpose, fundamental principles of new model are advised for Turkey.
\end{abstract}

Keywords: Adult training, social policy training, occupational health and safety training, labour administration.

\section{Özet}

Yetişkinlere yönelik sürdürülen sosyal politika eğitimleri birçok ülkede Çalışma Bakanlıkları bünyesinde örgütlenir. Türkiye'de de bu görev Çalışma ve Sosyal Güvenlik Bakanlı̆gl'nın bă̆lı kuruluşu olan Çalışma ve Sosyal Güvenlik Eğitim ve Araştırma Merkezi tarafindan yürütülür. Bu çalışmada Merkez'in yürüttügü sosyal politika ĕgitimlerinin yönetimi incelenmiş, eğitim faaliyetlerinin nasıl iyileştirileceği tartışılmıştır. Bu faaliyetler çalışma yönetimi kapsamında sistem analizi tekniğiyle ele alınmıştır. Kurum incelenirken, kuruluş yasasında belirtilen amaç ve görevlerin daha etkili bir biçimde, sosyal politika perspektifine uygun olarak yerine getirilmesi için yeni bir mevzuatın ve örgütlenmenin gerekli olduğu tezi savunulmuş; yeni bir modele ilişkin temel ilkeler sunulmuştur.

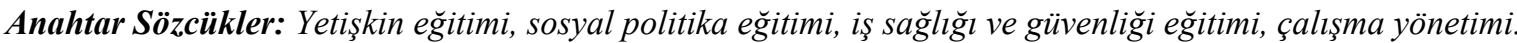

\footnotetext{
${ }^{1} \mathrm{Bu}$ makale Uludağ Üniversitesi, James Cook University ve RMIT University ortaklığınca 17-21 Haziran 2012 tarihleri arasında Bursa'da düzenlenen 1. Uluslararası Disiplinlerarası Sosyal Araştırmalar Konferansında sunulmuş olan “Türkiye'de Yetişkinlere Yönelik Sosyal Politika Eğitimlerinin Yönetimi Üzerine Bir İnceleme” adlı bildirinin gözden geçirilmiş ve genişletilmiş halidir.
} 
Çalışma yönetimi ve yetişkinlerin sosyal politika eğitimleri yakın ilişki içindedir. Çünkü bu etkinlik ağırlıklı olarak çalışma yönetiminin ana aktörü olan Çalışma ve Sosyal Güvenlik Bakanlığı (ÇSGB) ile bağlı ve ilgili kuruluşları tarafından yürütülmekte, özel eğitim kuruluşlarının katkısı ise sınırlı kalmaktadır. Ayrıca, çalışma yönetimiyle ilgili ulusal ölçekli başka kamu kurum ve kuruluşları da bu etkinliğe katkı yapmaktadır. Bu kurumlara Sağlık Bakanlığı, Milli Eğitim Bakanlığı (MEB), Kalkınma Bakanlığı, Aile ve Sosyal Politikalar Bakanlığı, Bilim Sanayi ve Teknoloji Bakanlığı, Türk Standartları Enstitüsü (TSE), Türkiye İstatistik Kurumu (TUIKK), Türk Akreditasyon Kurumu (TÜRKAK), Türkiye Orta Doğu ve Amme İdaresi Enstitüsü (TODAİE), Türkiye Bilimsel ve Teknolojik Araştırma Kurumu (TÜBİTAK) ve Mesleki Yeterlilik Kurumu (MYK) örnek olarak gösterilebilir. Ayrıca işçi ve işveren sendikaları, üniversiteler, iş sağllğg ve güvenliği alanında çalışan çeşitli vakıf ve dernekler de çalışma yönetimiyle ilgili diğer sivil toplum kuruluşlardır (Piyal, 2005).

Sosyal politika eğitimlerinin yönetimi ağırlıklı olarak Çalışma ve Sosyal Güvenlik Eğitim ve Araştırma Merkezi'ndedir (ÇASGEM). Bu merkez dışında diğer kamu kurum ve kuruluşlarının da bir takım görevleri bulunmasına rağmen bahse konu eğitimler 1955 yılından günümüze bu Merkez tarafından yürütülmektedir. Fakat yürütülen etkinlikler hem kurumsal anlamda, hem de eğitim içeriği açısından çalışma yönetiminin temel etkinlik alanlarını tam olarak kapsamamakta ve Merkezin çıktıları politika yapıcılar için kaynak üretememektedir. Hâlbuki Uluslararası Çalışma Örgütü'nün (UÇÖ) 158 Sayılı Tavsiye Kararı, Çalışma Bakanlıklarını; istihdam, sosyal politika gibi alanlarda ihtiyaç duyulan bilgilerin toplandığı, ülke çapında yürütülen hizmetlerin koordine edildiği bir merkez olarak kodlamaktadır. Sosyal politika alanı bilindiği gibi birçok disiplini barındırır ve yetişkinlerin sosyal politika eğitimi de çok geniş bir alanı kapsar. Tek bir makalede bu alanların tümünü kapsayan bir eğitim ve araştırma yönetimi incelemesi yapılması mümkün değildir. $\mathrm{Bu}$ nedenle çalışmada inceleme konusu olarak
Merkez faaliyetlerinin yönetimi seçilmiştir. Bu konunun seçilmesinin diğer nedeni ulusal bilimsel yazında çalışma yönetimiyle ilgili konulara yeterince ilgi gösterilmemiş olmasıdır (Çiner, 2007: 260).

$\mathrm{Bu}$ çalışmada sistem analizi tekniği kullanılmış, kurumun son dönem faaliyetlerinin analizinde ise ağırlıklı olarak katılımcı gözlem tekniği tercih edilmiştir. Yönetimin ve yönetim sorunlarının eğitim ve araştırma üzerindeki etkilerinin saptanmasını sağlayacak en temel yöntemlerden biri, katılımcı gözlemdir. Bu nedenle yazarın son dokuz yılda ÇSGB, ÇASGEM ve diğer kamu kurumlarında edindiği mesleki deneyim de makaleye yansıtılmıştır.

Makale, Merkez tarafından yürütülen eğitimlerin tarihsel süreç içinde akademik (1955-1972), teknokratik (1972-2003) ve bürokratik (2003-2013) bir etkiyle şekillendiği tezi üzerine oturtulmuş ve üç ana bölümde ele alınmıştır. İlk bölümde çalışmanın kavramsal çerçevesi açıklanmıştır. İkinci bölümde Merkezin tarihsel gelişimi, örgütsel yapı ve eğitimlerin yapısı kaba fırçayla resmedilmiştir. Son bölümde, saptanan sorunlardan yola çıkılarak, var olan sistemin hangi temelde dönüştürülmesi gerektiği incelenmiş ve yeni bir örgütlenme modelinin temel bileşenlerine yönelik ilkeler sunulmuştur.

\section{Kavramsal Çerçeve: Çalışma Yönetimi Bağlamında Sosyal Politika Eğitimleri}

Uluslararası Çalışma Örgütü'nün 1978 tarihli ve 150 sayılı Çalışma Yönetimi Sözleşmesi ve 158 sayılı Tavsiye Kararı çerçevesinde çalışma yönetimi; ulusal çalışma politikasını hazırlayıp yürütecek, denetleyip değerlendirecek ve eşgüdümünü sağlayacak kurumsal yapı olarak tanımlanabilir². UÇÖ'nün 150 Sayılı Sözleşmesinin 'sözleşmenin amacı' başlığı altındaki 1.maddesinin (a) fıkrasında çalışma yönetimi "ulusal çalışma politikasındaki kamu yönetimi faaliyetleri" olarak tanımlanmıştır. Piyal (2005) çalışma yönetimini, "tutarlı bir ulusal politikayı,

\footnotetext{
2 Türkiye 150 Sayılı Çalışma Yönetimi Sözleşmesi ile 158 Sayılı Tavsiye Kararını onaylamamıştır.
} 
eşgüdümü sağlanmış bir sistem sayesinde etkili ve verimli bir hizmet üretimine dönüştüren ve bu amaçla çalışanların, çalıştıranların ve örgütlerinin etkin katılımını, yeterli insan gücü ve maddi kaynakla bütünleştirmeyi başaran bir örgüt" şeklinde tanımlamaktadır.

\section{0 sayılı Sözleşme'nin birinci} maddesinin (a) fikrasında yapılan tanım, sözleşmenin ilerleyen maddelerinde ayrıntılı olarak açıklanmıştır. Buna göre, çalışma yönetimi sistemi; çalışma yönetimi ile ilgilenen ve sorumlu olan tüm bakanlık birimlerini, kamusal kuruluşları, bölgesel, yerel ya da merkezi olmayan yönetimin her türlü biçimi ve bu kuruluşların faaliyetlerinin kurumsal bir çerçevede işçi ve işveren kuruluşlarının katılımıyla eşgüdüm içerisinde yürüdüğü bütünsel bir yapıyı ifade eder (UÇÖ, 1978a).

Sözleşmede getirilen bu açıklamaların uygulamada daha iyi anlaşılabilmesi için aynı yıl kabul edilen 158 Sayılı Çalışma Yönetimiyle ilgili Tavsiye Kararı'nda ise, çalışma yönetiminin ana etkinlik konuları olan; çalışma standartları, çalışma ilişkileri, istihdam ve çalışma yaşamı alanında araştırma başlıklarında idarenin sosyal taraflarla birlikte hareket etmesi gerektiği belirtilmiştir (UÇÖ, 1978b). Böylece, çalışma yaşamında eğitim etkinliklerinin işçi ve işveren kuruluşlarından bağımsız biçimde yürütülemeyeceği öngörülmüştür.

Yukarıda açılanan düzenlemeler bağlamında çalışma yönetiminin temel etkinlik alanları dört başlık altında toplanabilir. Bunlar; çalışma normları, istihdam, mesleki ilişkiler ve çalışma yaşamında eğitim ve araştırmadır. Çalışma normları; çalışma koşulları, ücretler, istihdam koşulları, iş sağlığı ve güvenliği, çalışma ortamı, sosyal güvenlik ile iş teftişinden; istihdam etkinlik alanı ulusal istihdam politikası, işsizlik sigortası, mesleki eğitim, mesleki yönlendirme ve istihdam hizmetlerinden; mesleki ilişkiler etkinlik alanı; işverenlere ve işçilere yönelik hizmetler, toplu pazarlık ve toplu uyuşmazlıkların çözümünden; çalışma yaşamında eğitim ve araştırma etkinlik alanı ise; eğitim, araştırma, bilgi toplama ve geleceğe yönelik çözümleme alt başlıklarından oluşmaktadır (Piyal, 2009:
251-259). Bu çerçevede eğitim ve araştırma, çalışma yönetimi kapsamındaki diğer etkinlik alanları içinde yetişkinlere yönelik sosyal politika eğitimleri ile politika ve strateji belirlemek için yapılan araştırmaları kapsar.

Sosyal politika bilim alanı doktrinde dar ve geniş anlamlarıyla tanımlanmıştır. Dar anlamiyla sosyal politika; "toplumda var olan sosyal sınıfların ilişkileri, hareketleri, savaşımları ve çelişkileri karşısında devleti ve hukuksal düzeni ayakta tutmaya ve korumaya dönük çalışmaları içeren bir düşünce bütünüdür" (Talas, 1990: 31). Geniş anlamda sosyal politika ise; sanayi devrimi öncesi dönemi de içine alan ve toplumda işçi ve işveren sınıfları arasındaki ilişkiler dışında, korunmaya muhtaç olan tüm kesimleri kapsayan bir tedbirler bütünü olarak tanımlanabilir (Tuna ve Yalçıntaş, 1999: 28-29). Kadınlara, çocuklara, yaşlılara, özürlülere yönelik politikalar da geniş anlamda sosyal politikanın ilgi alanına giren konulardır (Koray, 2000: 11). Her iki tanımı kapsayan bir tanıma göre sosyal politika; "toplumun bağımlı çalışan, ekonomik yönden güçsüz ve özel olarak bakım, gözetim, yardım, destekleme gereksinimi duyan kesimlerinin ve gruplarının karşılaştıkları ya da karşılaşabilecekleri risklere, olumsuzluklara karşı en geniş biçimde korunmalarına yönelik kamusal politikaları konu alan bir bilim dalıdır" (Altan, 2006: 5; Akan, 2011: 32).

Sosyal politika en genel anlamiyla, toplumun korunmaya muhtaç kesimlerine yönelik politikalar bütünü olmakla birlikte refah ve refahın dağılımıyla ilgili kamu politikaları ve önlemlerini içerir (Heintz ve Lund, 2012). Bu durumda yetişkinlere yönelik sürdürülen sosyal politika eğitimleri de hedef olarak refah dağılımından daha fazla pay almak için çaba gösteren çalışanlara yönelik olmalıdır. Bu durumda söz konusu eğitimlerin ana hedef kitlesi, çalışanlar ve işsizlerdir. Devletin sosyal politikasını belirleyen ve yürüten kurumlardan biri de ÇSGB olduğuna göre, bu eğitimlerin bir sosyal politika girişim yöntemi ve kamu politikası olarak ÇSGB bünyesinde yürütülmesi 
doğrudur. ${ }^{3}$ Gerçekten, çalışma yönetimi ile sosyal politika birbirinden ayrilamaz. Temel sorun; birbirleriyle bu kadar yakın ilişki içinde olmalarına karşın, çalışma yönetimine yön veren karar alıcıların karar alırken konuya bir genel eğilim olarak, sosyal politika açısından bakmamalarıdır. Dolayısıyla sorunlar ekonomik ve teknik nedenlerle çözülemiyor olsa da, çoğu sorun için çözümsüzlük farklı nedenlere bağlıdır. Bilgi ve öneri eksikliği ve çözüm için gerekli tutum ve davranış özelliklerinin geliştirilememesi belirleyici nedenleridir (Piyal, 2005). Hâlbuki UÇÖ'nün 150 Sayılı Sözleşmenin 6. Maddesinin 1. Fıkrasında; "Çalışma yönetimi sisteminin içinde, ulusal çalışma politikasının yeniden gözden geçirilmesi, kontrol edilmesi, koordinasyonu ile hazırlanmasında sorumlu olacak ve bundan başka kamu yönetimi sınırı dâhilinde bir araç olan kanun ve düzenlemelerin hazırlanması ve uygulanması için uygun olan ehil bir yapı olmalıdır" (UÇÖ, 1978a) denilmektedir.

Şekil 1'de yetişkinlere yönelik sosyal politika eğitimlerinin nasıl örgütlenmesi gerektiğine ilişkin temel unsurlar belirtilmiştir. Şekil 1 incelendiğinde bir eğitim ve araştırma sisteminin siyasi kararlar, stratejik kararlar, yönetsel kararlar ve işlemler olarak dört ana unsurdan oluşan bir çerçeve içinde işlerlik kazanabileceği gösterilmiştir.

Öncelikli olarak belirtmek gerekir ki; bir eğitim ve araştırma sisteminin kurulmasındaki temel amaç; sonuç odaklı işler yapmaktır. $\mathrm{Bu}$ ise belirli hedefler için örgütlenmiş bir yapı ile olabilir. Eğitim ve araştırma sisteminin etkin bir şekilde işleyebilmesi için siyasi otoritenin çalışma yaşamıyla ilgili eğitim ve araştırma sisteminin nasıl bir işleyiş içinde olması gerektiğini tanımlaması ve bu yönde bir irade göstermesi gereklidir. $\mathrm{Bu}$ noktada siyasi otorite çalışma

\footnotetext{
3 Birçok ülke incelemesinde, çalışma yaşamında eğitim ve araştırmanın bahse konu ülkenin çalışma bakanlığ1 tarafından üstlenilmiş bir görev olduğu veya bu görevin bakanlı̆̆ın ve sosyal tarafların kaynak sağladıkları, ama idari ve mali özerkliği bulunan bir yapı tarafından üstlenildiği görülmektedir.
}

yaşamındaki öncelikli sorun alanlarına ilişkin somut kararlar almalıdır. Çünkü bir sistemin öncelikli görevi, o ülkedeki sorunların çözümüne yönelik belirlenmelidir. $\mathrm{Bu}$ bağlamda genel sorun; UÇÖ Anayasasında da belirtildiği üzere; toplumsal barışın korunmasına katkı yapmak, özel sorun ise Türkiye'de çalışma yaşamının sorunlarına çözüm üretecek politikaları yaşama geçirmektir. Böyle bir siyasi irade ortaya konulduktan sonra ikinci adım; alınacak stratejik kararlar ile bu iradenin çalışma yaşamı üzerinde yaratacağı etkinin tespitidir. Bunun için çalışma yaşamına, işçilerin ve sendikaların sorunlarına, kamu personelinin ihtiyaçlarına dönük konular tespit edilir ve stratejik kararlar içinde bu sorun alanlarının nasıl çözüleceğine ilişkin temel yöntemler belirlenir. Örneğin iş sağlığı ve güvenliği uzmanlarının eğitimi gerekli ise bu eğitimler uygulamaya dönük olmalı ve işbaşındaki işçinin de eğimini içerecek şekilde tasarlanmalıdır. Eğer sorun; toplu sözleşme sisteminin işleyişi ise bu noktada sendikacılara yönelik toplu iş sözleşmesi tekniği eğitimi yapılmalıdır. $\mathrm{Bu}$ ve benzeri birçok örnek verilebilir. Üçüncü adım alınan stratejik kararları uygulamaya geçirecek olan yönetim ve hizmet örgütlenmesinin oluşturulması sürecidir. Bunun için alınan stratejik kararın içeriğini uygulamaya dökebilecek nitelikte bir hizmet örgütlenmesi ile süreci yönetebilecek kapasitede yöneticiler belirlenir. Son aşama ise eylem aşamasıdır. Bu eylemler; eğitim ve araştırma faaliyetleri yoluyla politika belirleyicinin iradesinin çalışma yönetimiyle ilgili faaliyet alanlarına yansıması şeklinde kendini gösterir. 


\section{Şekil 1: Eğitim ve Araștırma Sisteminin Temel Bileșenleri}

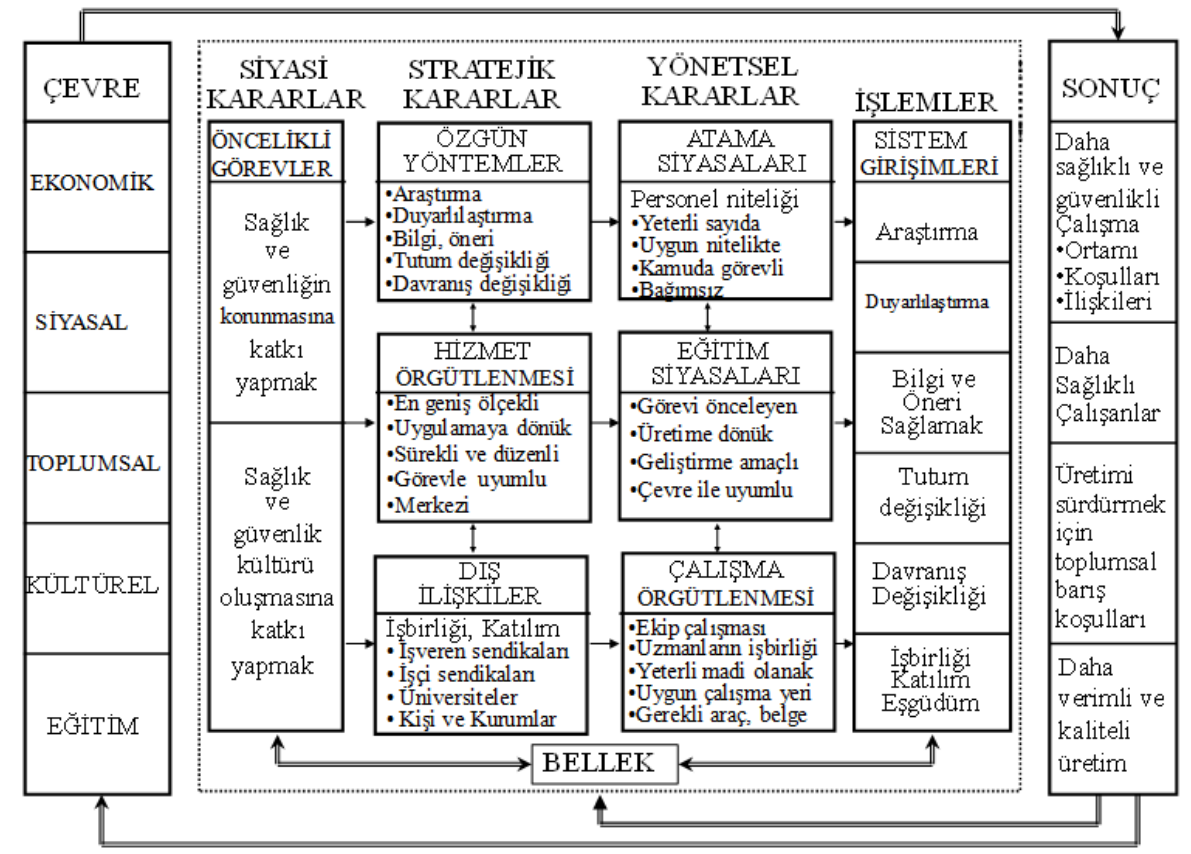

Kaynak: Derien vd. (1993) den uyarlayan: Piyal, 2009: 315.

\section{Türkiye'de Yetişkinlere Yönelik Sosyal Politika Eğitimleri}

Sistem analizinin ilk aşaması olan siyasi irade aşaması ilk olarak I. Dünya Savaşını sona erdiren antlaşmaların içinde işçi-işveren ilişkilerinin nasıl düzenleneceğine ilişkin hükümler konulması ile başlamıştır. Bu hükümlere istinaden I. Dünya Savaşı sonrası Versay Barış Antlaşmasının getirmiş olduğu hükümlere göre 1919 yilında kurulan Uluslararası Çalışma Örgütü (Işıklı, 2003: 120), II. Dünya Savaşı sonrasında 1944 yılında "Filedelfiya Beyannamesi"ni kabul etmiştir. Bu beyanname ile yaşam şartları üzerinde inkâr edilemez etkileri olan ekonomik gelişmeler konusunda UÇÖ'nün sorumlulukları belirtilmiştir (Turan, 1979: 136). Bu gelişmeler ışığında UÇÖ dünya çapında iş barışı ve toplumsal adaleti sağlamak amacıyla çeşitli faaliyetlere başlamıştır. Bu faaliyetler arasında birçok ülkede bölge enstitüleri ve faaliyet merkezleri kurmak suretiyle bölgenin çalışma yaşamına ilişkin belirli standartlar getirmek de vardır. Bu makalenin temel inceleme konusu olan, Türkiye'de yetişkinlere yönelik sosyal politika eğitimlerini yürüten kurumsal yapı da bu anlayışın sonucu olarak kurulmuştur. $\mathrm{Bu}$ amaçla Türkiye'de II. Dünya savaşını müteakip atılan adımlar ile Yakın ve Orta Doğu Faaliyet Merkezi ${ }^{4}$ ile 1955 yılında Yakın ve Orta Doğu Çalışma Enstitüsü ${ }^{5}$ (YODÇE) kurulmuştur. Öyle ise, o dönemin karar alıcıları bu konuda bir irade göstererek bazı uluslararası kuruluşlar

4 TBMM (1952) Milletlerarası Çalışma Bürosu ile Türkiye Cumhuriyeti Hükümeti arasında İstanbul'da Yakın ve Orta Doğu İş Gücü Faaliyet Merkezi kurulması için Cenevre'de imzalanan Anlaşmanın onanması hakkında 5947 sayılı Kanun, Resmi Gazete Tarihi: 13 Haziran 1952, Sayısı: 8134.

${ }^{5}$ UÇÖ ve Türkiye Cumhuriyeti arasında 17.01.1955 tarihinde, 10 Temmuz 1953 tarih ve 6114 sayll Yasaya dayanarak hazırlanan, 13 Sayılı Ek Anlaşma ile UÇÖ tarafından YODÇE kurulmuştur. 6114 sayılı Yasa 03 Temmuz 1953'de kabul edilmiş ve 10 Temmuz 1953 tarih ve 8454 Sayılı Resmî Gazetede yayınlanmıştır. Daha önceki çalışmalarımda 6114 sayılı yasanın tarihi 05 Eylül 1951 olarak gösterilmiştir. $\mathrm{Bu}$ tarih Milletlerarası İşbirliği Teşkilâtı Genel Sekreteri Fatih Rüştü Zorlu ile Birleşmiş Milletler ile Türkiye Cumhuriyeti Hükümeti Nezdinde Birleşmiş Milletler Teknik Yardım Özel Temsilcisi Milton Winn arasındaki yazışmalara ilişkin tarihtir (EC). 
aracılığ işçi işveren ilişkilerinin belirli standartlar üzerinde şekillenmesini arzu etmişlerdir. Eğitim ve araştırma yoluyla çalışma yönetimine ilişkin politika oluşturma noktasında atılması gerekli ilk adım olan siyasi karar alma mekanizması da bu şekilde işlemeye başlamıştır. $\mathrm{Bu}$ kararın üstüne öncelikle uluslararası antlaşmalar imzalanmış ve bunların Türk idari sistemindeki karşılığı olan kurumlar kurulmuştur.

YODÇE beş yıl süreyle UÇÖ yönetimi altında faaliyetlerini sürdürmüş, 27 Şubat 1960 yılında kabul edilen 7460 sayılı Yasa ile Çalışma Bakanlığı'na bağlanmıştır. ${ }^{6}$ Merkezin temel etkinlik alanlarını düzenleyen Teşkilât Yasasının ikinci maddesinde görevler belirlenmiştir.7 Kuruluş Yasasına göre Merkezin üç temel etkinlik alanı bulunmaktadır. Birincisi çalışma yaşamıyla ilgili geniş bir çerçeve içindeki konulardan oluşan araştırma faaliyetleri, ikincisi sosyal taraflar ile işgücü

\footnotetext{
${ }^{6}$ Bu devir işlemi ve kanun tasarısını görüşmek üzere 18 Şubat 1960' da TBMM'nde bir kurul kurulmuştur, Türkiye Büyük Millet Meclisi (1960) Zabit Ceridesi, Sabık Zabıt Hulâsası, Kırkıncı İnikat, 18.II.1960 Perşembe, Devre: XI, Cilt: 11, İçtîma: 3, Birinci Celse. Kurulun çalışmaları sonucunda Yakın ve Orta Doğu Çalışma Enstitüsü'ne ilişkin 7460 Sayılı Kuruluş Yasası 27 Şubat 1960 tarihinde TBMM'de kabul edilmiştir, Türkiye Büyük Millet Meclisi (1960) Zabıt Ceridesi, Sabık Zabıt Hulâsası, Ellinci İnikat, 28.II.1960 Pazar, Devre: XI, Cilt: 12, İçtîma: 3, Üçüncü Celse. Kabul edilen kanun 29 Şubat 1960 tarihli ve 10444 sayılı Resmî Gazete' de yayınlanmıştır.

77460 Sayılı Kuruluş Yasası'nın ikinci maddesinde belirlenmiş görevler özet olarak şunlardır; çalışma hayatı, sosyal güvenlik, iş sağlığı ve güvenliği, işçi işveren ilişkileri, istihdam, verimlilik, toplam kalite yönetimi, iş piyasası etütleri, ergonomi, çevre, ilk yardım, iş istatistikleri ve benzeri konular ile işyerindeki sağlık ve güvenlik risklerini önlemek ve koruyucu hizmetleri yürütmek üzere görevlendirilecek işyeri hekimi, mühendis, teknik eleman, hemşire ve diğer sağlık personeline iş sağlı̆̆ ve güvenliği konusunda eğitim programları hazırlamak, eğitim vermek veya eğitim hizmeti satın almak, sertifikalandırmak, bu konularla ilgili araştırmalar yapmak veya yaptırmak ve çalışma mevzuları ile ilgili araştırmalar ve incelemeler yapmak ve bu mevzularda belge toplamaktır.
}

piyasasının aktörlerine yönelik eğitim faaliyetleri, üçüncüsü ise ÇSGB bağlı ve ilgili kuruluşlarındaki personel için hizmet içi eğitim faaliyetleridir. Öncelikli olarak belirtilmelidir ki ilk iki faaliyet alanı ile üçüncü faaliyet alanı farklı hedef kitlelere sahiptir. İk iki alan ağırlıklı olarak iş kanununa tabi çalışan kişilerin ve bu statüdeki personeli istihdam eden kuruluşların çalışma yaşamıyla ilgili ihtiyaç duydukları eğitim ve araştırma faaliyetlerini içermektedir. Üçüncü faaliyet alanı ise bakanlığın bürokrat ve teknokrat personeline yönelik hizmet içi eğitimler düzenlemektir ki bu ise çalışma yaşamına yön veren uzmanların ve politika belirleyicilerin eğitimidir ve farklı bir süreç ve ihtisas gerektirir. Aralarındaki temel fark; çalışanlara ve sendikacılara yönelik eğitimlerin içinde farklı işkollarında çalışan işçiler, ara yöneticiler, işçi temsilcileri, sendikacılar varken diğer tarafta belli bir eğitim seviyesinin üstünde olan ve statü hukukuna göre çalışan uzmanlar vardır. Dolayısıyla bu fark, farklı eğitim yöntem ve tekniklerini kullanma ihtiyacını doğuran programların hazırlanmasını gerektirir. İkinci temel fark; birinci gruptaki hedef kitle, üretimin devamlılığından, iş barışından, iş sağllğı ve güvenliğinden doğrudan etkilenen işçi ve işveren kesimlerinden oluşurken ikinci grup; bu devamlılığın sağlanabilmesi için görev üstlenmiş devlet memurlarını kapsamaktadır. Diğer bir fark; hedef kitlelerin farklı hukuki statülere göre istihdam edilmeleridir. İşçiler sözleşme hukuku prensiplerine göre (özel hukuk), memurlar ise statü hukuku ilkelerine (Aktay, 2000: 5-6) göre (kamu hukuku) istihdam edilmektedirler. $\mathrm{Bu}$ bağlamda düşünüldüğünde söz konusu yasal düzenlemenin çok geniş bir perspektif ile piyasada ve devlette çalışan her kişiyi kapsadığı tespiti yapılabilir. Öncelikle bu durum, yasanın, belli bir politikanın uygulamaya konulmasını sağlayacak bir amaç içermediğini göstermektedir. Yasanın ikinci maddesinin üçüncü ve devam eden fıkraları ise çalışma yaşamıyla ilgili danışmanlık, araştırma ve yayın konularını kapsamaktadır. Bunlar ise her eğitim ve araştırma merkezinde olması gerekli temel faaliyet alanları olarak doğru belirlenmiştir. 
1972 yılına kadar faaliyetlerini İstanbul'da sürdüren Enstitü, Çalışma Bakanlığı kararı uyarınca 1972 yılında Ankara'ya taşınmıştır8. 1972'ye kadar olan dönemi akademik dönem olarak tanımlayabiliriz. Enstitü'de 1972 - 1985 döneminde birkaç çeviri ${ }^{9}$ dışında herhangi bir çalışma yapılmamıştır. 1983 yılında ÇSGB yeniden yapılandırılırken, adı Yakın ve Orta Doğu Çalışma Eğitim Merkezi $^{10}$ (YODÇEM) olarak değiştirilen Enstitü, bir eğitim merkezine dönüştürülmüştür. Bu değişim Merkezdeki etkinliklerinin bir süre için canlanmasını sağlamış, Merkezde ağırlıklı olarak iş sağlığı ve güvenliği ile iş hukuku alanlarında kısa süreli seminerlerin yanı sıra, Bakanlık personeline yönelik hizmet içi eğitim etkinlikleri düzenlenmiştir. Bu etkinlikler Merkez dişından katkı veren iş müfettişleri, öğretim üyeleri ya da uzmanlar tarafından yürütülmüştür. Bu dönem Merkezde ağırlıklı olarak iş müfettişlerinin etkin olduğu teknokratik dönem olarak tanımlanabilecek dönemdir. Beklenen faydayı sağlayamayan Merkezin adı 2003 yılında yapılan değişiklik ${ }^{11}$ ile ÇASGEM ${ }^{12}$ olarak

8 Yakın ve Orta Doğu Çalışma Enstitüsü'nün Ankara'ya taşınmasının gerekçesi için bakınız: Cam, 2012.

${ }^{9} \mathrm{Bu}$ çalışmalar için bakınız: Cam, 2012.

10 Çalışma ve Sosyal Güvelik Bakanlığı'nın Teşkilât ve Görevleri Hakkında 14 Aralık 1983 tarihli, 184 sayılı Kanun Hükmündeki Kararnamenin "Bağlı Kuruluşlar" başlıklı 32. maddesinde Enstitünün adı "Yakın ve Orta Doğu Çalışma Eğitim Merkezi" olarak değiştirilmiştir. Daha sonra 3146 sayılı yasanın Bağlı Kuruluşlar başlıklı 30. Maddesinin b fıkrasında da bu hüküm korunmuştur.

${ }^{11} \mathrm{Bu}$ değişikliğin gerekçesi TBMM tutanaklarında şu şekilde açıklanmıştır: “7460 sayılı kanunun çok sayıda maddesi 40 yılı aşkın bir süreç içerisinde uygulanabilme özelliğini kaybetmiştir. Bakanlık, bağlı ve bağlı kuruluşun ilgili kuruluşu ile diğer kamu ve özel sektör çalışanlarına, işveren ve yönetici personeline çalışma hayatı ve sosyal güvenlik alanlarında eğitim, araştırma, inceleme, yayın, dokümantasyon ve danışmanlık hizmetlerini verebilecek, bu alandaki gelişmeleri ülkemize kazandırabilecek çağdaş bir eğitim ve araştırma kurumuna büyük ölçüde ihtiyaç duyulmaktadır. Bu ihtiyacı karşılayabilmek amacıyla Yakın ve Orta Doğu Çalışma Eğitim Merkezi yeniden değiştirilmiş ve bir yenilik olarak kuruma Çalışma ve Sosyal Güvenlik Eğitim Uzman Yardımcısı kadroları ihdas edilmiştir (Cam, 2012). 2003'ten sonra yapılan değişiklik ile Merkez bürokratik etkinin tam anlamı ile hissedildiği bir kurum haline dönüşmüştür.

Yapılan yasa değişikliği incelendiğinde kariyer meslek mensubu ve ikinci bir başkan yardımcısının istihdamı dışında önemli bir değişiklik yapılmamıştır. Nitekim yasa değişikliği gerekçesinde belirtildiği üzere; “7460 sayılı kanunun çok sayıda maddesi kırk yılı aşkın bir süreç içerisinde uygulanabilme özelliğini kaybetmiştir" ifadesi bu yasa değişikliği ile düzeltilmemiştir çünkü uygulanabilme özelliğini kaybeden maddelere neredeyse dokunulmamıştır. Halen yasanın birçok maddesi, maddeyle ilgili ikincil mevzuat olmaması nedeniyle uygulanabilme özelliği taşımamaktadır.

Yasanın temel eksikliklerinden bir diğeri; Merkezde yürütülmesi öngörülen görevlerin genel başlıklardan oluşması ve istihdam edilmiş kariyer uzmanlarının hangi alanda uzmanlaşacakları noktasında bir belirsizlik olmasıdır. Hâlbuki diğer ülkelerin benzeri kuruluşları incelendiğinde, kurumların ana hizmet birimlerinin uzmanlaşma üzerine yapılandırıldığ1 görülür. ${ }^{13}$ ÇASGEM'in kuruluşundan günümüze faaliyet gösterdiği eğitim konu başlıkları bir uzmanlaşma alanı olarak seçenek oluşturabilirken, yasada

yapılandırılarak, Çalışma ve Sosyal Güvenlik Eğitim ve Araştırma Merkezinin kurulması için gerekli düzenlemeler yapılmıştır". Türkiye Büyük Millet Meclisi (TBMM) (2003) Sosyal Güvenlik Kurumu Teşkilâtının Kurulması ile Bazı Kanun ve Kanun Hükmünde Kararnamelerde Değişiklik Yapılması Hakkında Kanun Teklifi ile Gerekçesi, Kayseri Milletvekili Hasan Basri Üstünbaş tarafından Meclis Başkanlığına Sunulan Dilekçe, Kayıt No: 9444, 22531.

${ }^{12}$ Çalışma ve Sosyal Güvenlik Eğitim ve Araştırma Merkezi.

13 Örneğin Çek Cumhuriyeti Çalışma ve Sosyal İşler Araştırma Enstitüsü'nde istihdam edilmiş otuz uzman, Enstitüde farklı uzmanlık bölümlerinde çalışmaktadır (RILSA, 2011). Aynı işbölümü Japonya, Litvanya ve Hindistan'ki örneklerde de ihtiyaçlara yönelik olarak belirlenmiştir (JILPT, LSRC, VVGNLI, 2011). 
belirtilen ve şimdiye kadar üzerinde çalışma yapılmamış konu başlıkları da bir başka seçenek olma özelliğine sahiptir. Ancak yönlendirici bir yönetim yapısının olmaması ve gerçekleşen eğitimlerin bir plan çerçevesinde yapılmaması bu durumu zorlaştırmaktadır.

$\mathrm{Bu}$ bağlamda bir değerlendirme yapıldığında hem faaliyet gösterilen alana ait farklı hedef kitlelerin bir arada olması hem de faaliyete ilişkin konu başlıklarının sistematik bir biçimde belirlenmemiş olması Merkezin hedeflerinin bir siyasi tercih olarak belirlenmediğini göstermektedir. Böyle bir tercihin olmaması sistemin işleyişinde de aksaklıklara neden olmaktadır. Bu aksaklıklar kendisini ağırlıklı olarak organizasyon üzerinde göstermektedir. Örneğin; 2003-2013 yılları arasında Merkez Başkanı sekiz kez değiştirilmiştir. Her yöneticinin çalışma anlayışındaki farklılıklar ve yerleşik bir kurum kültürünün olmayışı kurumda yapılan işlerin niceliksel ve niteliksel olarak bir istikrar çerçevesinde yürümediğinin göstergesi sayılabilir.

\section{Merkezin Görevleri, Organizasyonu ve Programlarin Yapist}

Eğitim ve araştırma sistemi tasarımında sonraki adım yasal düzenlemelerin nasıl bir yöntem ile yaşama geçirileceğidir. Bunun için hizmet örgütlenmesi yapılır. $\mathrm{Bu}$ süreçte kimlerle işbirliği içinde çalışılacağ 1 ve hizmetin hangi hedef kitleye nasıl sunulacağı belirlenir. İlk iki adımın belirlenmesi sonucunda organizasyon yapisı belirlenir. Bu organizasyon kurulurken, hizmetin niteliğine uygun personel seçilir ve bu personelin özerk bir yapıda çalışabilecekleri güvence yasal olarak sağlanır (Piyal, 2009: 316-319). Merkezin organizasyon yapıs1, kurulduğu tarih olan 1955'ten günümüze kadar birçok değişiklik geçirmiştir.

Merkezdeki ilk kariyer personel istihdamı 2004 yılının sonunda başlamış ve 2012 yılına kadar dört farklı dönemde sürmüştür. ${ }^{14} 2013$ yılı verilerine göre kurumda

\footnotetext{
${ }^{14}$ Bu dönemler sırasıyla 2004, 2006 ve 2010 yıllarıdır. 2004 yılında 8 uzman yardımcısı istihdam edilmiş, 6's1 ayrılmıştır. 2006 yılında 10 uzman yardımcısı istihdam edilmiş 6'sı ayrılmıştır. 2011 yılında 13
}

dört Çalışma ve Sosyal Güvenlik Eğitim Uzmanı ve ondokuz Çalışma ve Sosyal Güvenlik Eğitim Uzman Yardımcısı çalışmaktadır. Merkez'in istihdam politikasındaki bu değişiklikten sonra bir ivme kazandığı ve etkinliklerinin çeşitlendiği belirtilebilir.

Merkezde istihdam edilen Eğitim Uzmanları ile Eğitim Uzman Yardımcılarının belli ihtisas bölümleri çerçevesinde örgütlenemiyor oluşu bir ara çözüm olarak bu ihtiyacın iç genelgeler ile düzenlenmesine neden olmaktadır. Fakat iç genelgelerin yasa veya yönetmelik hükümleri kadar bağlayıcı olmayan hukuki niteliği bu yapının verimli bir şekilde işlemesine engel oluşturabilmektedir. Dolayısıyla idare hukuku açısından alt yapısı daha sağlam düzenlemelere ihtiyaç vardır. Bir diğer sorun yönetici devri yüksekliğidir. Aşağıdaki tabloda Merkez yönetimindeki devir gösterilmiştir.

uzman yardımcisı 2012 yılında ise 7 uzman yardımcısı istihdam edilmiş makalenin yazıldığ 1 tarih itibariyle ayrılan olmamıştır. Sonuç olarak Merkezde, diğer yardımcı birimler personelinin yanında kariyer personeli olarak tanımlanabilecek 6 uzman ve 20 uzman yardımcisı bulunmaktadır. Kurumdan ayrılan uzman yardımclarının yeni kurum ve unvanlarına bakıldığı zaman kurumun tatmin edici bir iş ortamına sahip olmadığ $\breve{1}_{1}$ tespiti yapılabilir. İlk dönem istihdam edilen uzman yardımcılarının ayrıldıktan sonra geçtikleri kurumlar: Bankacılık Düzenleme ve Denetleme Kurumu, Radyo ve Televizyon Üst Kurumu, Enerji Piyasası Düzenleme ve Denetleme Kurumu, Türkiye Cumhuriyet Merkez Bankası, Orta Doğu Teknik Üniversitesi ve Avrupa Birliği bakanlığı'dır. İkinci dönem uzman yardımcılarının geçtikleri kurumlar: Telekomünikasyon Üst Kurulu, Sermaye Piyasası Kurulu, Adalet Bakanlığı Hâkimlik, Vakıflar Bankası Teftiş Kurulu, ÇSGB İş Teftiş Kurulu, Sosyal Güvenlik Kurumu'dur. 
Tablo 1: 2003-2012 Yılları Arası Yönetici Devri

\begin{tabular}{lllll}
\hline \multicolumn{3}{l}{ Yönetici } & \multicolumn{3}{c}{ Görev Süresi } \\
\hline $\mathrm{AB}$ & & 2003 & - & 02.2008 \\
$\mathrm{CD}$ & & 02.2008 & - & 09.2009 \\
$\mathrm{EF}$ & (vekâleten) & 09.2009 & - & 09.2010 \\
$\mathrm{GH}$ & (vekâleten) & 09.2010 & - & 04.2011 \\
$\mathrm{CD}$ & & 04.2011 & - & 06.06 .2011 \\
$\mathrm{GH}$ & (vekâleten) & 06.06 .2011 & - & 24.10 .2011 \\
II & (vekâleten) & 25.10 .2011 & - & 28.12 .2011 \\
$\mathrm{JK}$ & & 28.12 .2011 & - & \\
\hline
\end{tabular}

Yukarıdaki tablo incelendiği zaman son beş yılda yönetimde istikrar olmaması ve her yöneticinin farklı çalışma anlayışlarını benimsemesi genelgelerin işleyişine engel yaratmaktadır. Bu yasal altyapı eksikliği teşkilâtın yönetiminde zaman zaman profesyonel olmayan yaklaşımları beraberinde getirmektedir. Bürokratik müdahaleye son derece açı olan bu yapı zaman zaman nepotizm olarak adlandırılabilecek uygulamaları içeren özellikler gösterebilmektedir.

\section{Eğitim Yönetimindeki Dönüşüm: Akademik Anlayıştan Teknokrat Anlayışa, Teknokrat Anlayıştan Bürokrat Anlayışa}

Bir eğitim araştırma sisteminin oluşumu için gerekli olan ilk üç şartın; siyasi karar, yasal düzenleme ve organizasyon oluşturma süreçlerinden oluştuğunu belirttik. Tüm bu aşamaların arkasından gelen son aşamada ise sistem işlemeye başlar. Çalışma hayatıyla ilgili eğitim ve araştırma yapacak bir sistemin hedefinde iyileştirme ve bilinçlendirme olduğuna göre çalışma yönetiminin temel bileşenleri olarak sayılan alanlarda tutum ve davranış değişikliği yaratacak eylemler oluşturulmaya çalışılır (Piyal, 2009: 319). Bunu sağlayabilmek için kullanılabilecek en etkin yol eğitimdir. Dolayısıyla Merkezde yürütülen eğitim programlarının da bu amaca dönük oluşturulması gereklidir. Bu nedenle bu başlık altında Merkezin kuruluşundan günümüze nasıl bir eğitim politikası olduğu ve bunun nasıl yönetildiği incelenmiştir. Eğitimler hangi konular etrafında belirlenmekte ve nasıl bir yöntem ile hangi hedef kitleye sunulmaktadır? İlerleyen satırlarda bu soruya cevap aranmıştır.

Merkezde yürütülen eğitim faaliyetlerinin genel özelliği; eğitimlerin kısa süreli olmasıdır. Her yıl Kasım ayının son haftasında yapılan Danışma Kurulu ${ }^{15}$ toplantısında bir sonraki yılın eğitim hedefleri belirlenmekte ve hedeflenen eğitim sayısına ilişkin bir plan yapılmaktadır. Ancak Merkez, yapılan planlara göre değil piyasanın eğitim taleplerine göre faaliyet göstermektedir. $\mathrm{Bu}$ çelişki yüzünden planlanan hedefe ulaşabilmek için nitelik yerine nicelik ön plana çıkmıştır. Merkezin esnek hareket kabiliyetine sahip olması piyasa odaklı eğitim planlamayı mümkün kılmaktadır. Esnekliğin getirmiş olduğu bu olumlu taraf yanında, olumsuz taraf

15 Eğitim ve Araştırma Merkezi ile ilgili yönetmelikler hakkında görüş bildirmek, Merkez tarafından çalışma hayatı, sosyal güvenlik, işçiişveren ilişkileri, iş sağlı̆̆ı ve güvenliği, işyeri hekimliği, toplam kalite yönetimi, iş teftişi, istihdam, verimlilik, iş piyasası etütleri, ergonomi, çevre, ilk yardım, iş istatistikleri ve benzeri konulardaki eğitim, araştırma, danışmanlık, yayın ve diğer faaliyetlerini yönlendirme, Merkezinin yıllık faaliyetlerini değerlendirmek, Merkezinin çalışmalarının etkinliğini artırıcı ve bu çalışmaların performansının geliştirilmesi ile ilgili önerilerde bulunmak, Eğitim programının ve araştırma konularının güncel gelişmelere göre yenilenmesi, yayın konularının ihtiyaca cevap verebilmesi ve kalitenin yükseltilmesi, Danışmanlık fonksiyonunun geliştirilmesi konularında tavsiyelerde bulunmak amacıyla bir Danışma Kurulu kurulmuştur. Çalışma ve Sosyal Güvenlik Eğitim ve Araştırma Merkezi Danışma Kurulu Çalışma Usul ve Esaslarına Dair Yönetmelik, Resmî Gazete Tarihi: 31.12.2003, Resmî Gazete Sayıs1: 25333. 
ise her zaman talebe cevap verilememesidir. Çünkü henüz Merkezde belirli konularda uzmanlaşmış eğitimciler bulunmamaktadır. Sadece iş sağllı̆̆ ve güvenliği ve iş mevzuatı alanında belirli konu başlıklarında eğitimler verilmektedir. $\mathrm{Bu}$ nedenle Merkezde eğitim başlıkları çerçevesinde bir planlama ve düzenleme yapılmalıdır. Mevcut Eğitim uzmanı ve yardımcisı personel de bu düzenlemeye göre yetiştirilmelidir.

Genel olarak eğitim planlamasının amacl, kalkınma doğrultusunda belirlenen hedefi belli seçim önceliklerine ve bir öncelikler listesine koyarak sınırlı kaynakları bu öncelikli hedefler için kullanmaktır (Hesapçıŏlu, 1994: 8). Konu çalışma yönetimiyle ilgili bir eğitim planlaması olduğunda ise bu çalışma yönetimin temel faaliyet alanları ve öncelikli sorunlar dikkate alınarak yapılabilir. Örneğin iş teftiş sisteminin ve iş müfettişlerin niteliklerinin iyileştirilmesi, iyi belirlenmiş bir eğitim stratejisine dayanan planlama ve programlama ile sağlanabilir (ILO, 2001: X). Konu çalışma yönetimiyle ilgili hizmetiçi eğitim faaliyetlerinin organizasyonu ise bu durumda da çalışma yönetimi bağlamında personelin rol ve görevlerinin ne olduğu ve neler olmas gerektiği üzerinde bir planlama yapılmalıdır (Husband, 1980: 30-35). Aynı tespit çalışma yönetiminin tüm ilgi alanları için geçerlidir. Konu başlıkları ile ilgili temel sorun ve ihtiyaçların belirlenmesine yönelik bir fizibilite çalışması yapıldıktan sonra çalışma yönetimiyle ilgili gerek işgücü piyasasının gerekse çalışma yaşamının aktörlerinin ihtiyaç duyacağı eğitimler daha sistematik bir şekilde düzenlenebilir. Merkezde böyle bir planlama anlayışı olmadığı için sürdürülen faaliyetler de belirli standartlarda yürütülememektedir.

Merkez kuruluş yıllarında akademik bir anlayış üzerinde şekillenmiştir. Zaman içinde özellikle de 1960 yılından sonra bu akademik anlayışı sürdürme çabaları devam etmiştir (Cam, 2012). Ancak bu dönemde de Merkezin Çalışma Bakanlığı'nın bağlı bir kuruluş olması nedeniyle, yürütülen çalışmalar üzerinde önce teknokratik ve devamında ise bürokratik bir etki yaşanmıştır. Bu etkilerin açıklanabileceği en temel örnek; Enstitünün bir anda uluslararası niteliğini kaybetmesi ve klasik bir devlet kurumuna dönüşme sürecidir. Akademiden, Teknokrasiye ve Teknokrasiden Bürokrasiye dönüşme süreci olarak tanımladığım bu süreç Enstitünün 1960 yılında UÇÖ yönetiminden çıkması ile başlamış ve nihayetinde günümüze kadar süregelmiştir (ILO, 1967: 239). İlginçtir ki Enstitü henüz statü değiştirmeden önce yaşanmış tablo o zaman ki yönetim tarafından bir uyarı mahiyetinde tarihe bir not olarak düşülmüştür (Koçer, 1963: 2). Zaman içinde akademisyenlerin ve akademisyenlerden oluşan öğretmenler kurulunun Merkez üzerindeki etkisi 1985 yılındaki yeniden yapılanma ile zayıflatılmış ve 2003 yılında 7460 sayılı Kuruluş Kanununda yapılan değişiklik ile öğretmenler kurulu danışma kuruluna ${ }^{16}$ dönüştürülmüş ve üyelerinin büyük çoğunluğu ÇSGB ana hizmet birimleri ile ilgili kuruluşların bürokratlarından oluşturulmuştur. Kısaca değinilen bu süreç kurumun eğitim ve araştırma faaliyetlerinde konu uzmanlarının etkisini azaltmış ve bir süre sonra da yok etmiştir. Danışma Kurulu adından da anlaşılacağı üzere bağlayıcılığı olan bir kurul değildir.

Merkezin eğitimlerindeki değişim ise Tablo 2'de gösterilmiştir. Kuruluş yıllarında yakın ve orta doğu coğrafyasında bölgesel bir eğitim merkezi olan Enstitüde sürdürülen eğitimler 1960 sonrası azalmış, bir, üç ve beş günlük bilimsel bildirilerin sunulduğu ve uygulamadaki sorunların tartışıldığı bir platforma dönüşmüş, 1972'den sonra ise bu bilimsel ortam Enstitünün Ankara'ya getirilmesi ile birlikte yok olmuştur. Daha sonra eğitim faaliyetlerine başlayan Merkezin eğitim konu başlıkları da İş Teftiş Kurulu'nun etkisiyle iş sağlığı güvenliği ile iş mevzuatı çerçevesinde belirlenmiştir.

16 Çalışma ve Sosyal Güvenlik Eğitim ve Araştırma Merkezi Danışma Kurulu Çalışma Usul ve Esaslarına Dair Yönetmelik, Resmi Gazete Tarihi: 31.12.2003, Resmi Gazete Sayısı: 25333. 
Tablo 2: Eğitim İçeriğindeki Değișim

\begin{tabular}{|c|c|c|}
\hline Dönemler & Eğitim Konu Başlıklarındaki Değișim & $\begin{array}{c}\text { Araștırma ve Yaym } \\
\text { Faaliyetleri }\end{array}$ \\
\hline $1955-1960$ & $\begin{array}{l}\text { Ağırlıklı olarak yakın ve orta doğu ülkelerin } \\
\text { çalışma bakanlıkları personeline ve Türk çalışma } \\
\text { bakanlığı personeline yönelik hizmet içi eğitimler. }\end{array}$ & $\begin{array}{l}\text { Enstitünün faaliyetlerinin } \\
\text { duyurulduğu, aynı zamanda } \\
\text { birkaç bilimsel inceleme } \\
\text { makalesinin yayınlandığı } \\
\text { bülten. }\end{array}$ \\
\hline $1961-1972$ & $\begin{array}{l}\text { Hizmet içi eğitimlerden bilimsel seminerlere ve } \\
\text { uygulamaya dönük sorunların tartışıldığı bir, üç ve } \\
\text { beş günlük seminerlerin gerçekleştiği dönem. }\end{array}$ & $\begin{array}{l}\text { Enstitünün faaliyet alanuna } \\
\text { giren konularda bilimsel } \\
\text { araştırma ve derleme } \\
\text { yayınları. }\end{array}$ \\
\hline $1973-1984$ & Faaliyetlerin durduğu dönem & Üç çeviri yapılmıştır. \\
\hline $1985-2003$ & $\begin{array}{l}\text { İş hukuku ile iş sağlığı ve güvenliğinin teknik ve } \\
\text { sosyal boyutlarının günlük seminerler halinde } \\
\text { teknokratlar tarafından verildiği dönem. }\end{array}$ & $\begin{array}{l}\text { Çoğunlukla Bakanlık } \\
\text { Teknokratları tarafından } \\
\text { hazırlanmış tanımlayıcı kitap } \\
\text { çalışmaları ile sınırlı sayıda } \\
\text { bilimsel çalışma. }\end{array}$ \\
\hline $2004-2013$ & $\begin{array}{l}\text { İş hukuku ile iş sağlığı ve güvenliğinin teknik ve } \\
\text { sosyal boyutlarının günlük seminerler halinde } \\
\text { teknokratlar tarafından verildiği bir önceki döneme } \\
\text { ait etkinlikler devam etmiş, eğiticilerin eğitimi, } \\
\text { yöneticilerin eğitimi gibi eğitim metodolojisi ve } \\
\text { etkili yönetim tekniklerinin akademisyenler } \\
\text { tarafından verilmesine başlanmış ayrıca } \\
\text { Türkiye'nin AB'ye aday ülke konumuna gelmesi ile } \\
\text { birlikte AB proje süreci yönetimi eğitimleri de } \\
\text { etkinlik alanına dâhil olmuştur. }\end{array}$ & $\begin{array}{l}\text { Bu dönemdeki yayınların } \\
\text { tamamı bilimsel çalışmalardan } \\
\text { oluşmaktadır. }\end{array}$ \\
\hline
\end{tabular}

2003 yılındaki değişim süreci ile birlikte yetişkinlere yönelik sosyal politika eğitimleri çerçevesinde birçok yeni konu başlığı belirlenmiş ancak talep olmaması nedeniyle bu eğitimler gerçekleşememiştir. Talep olmamasının temel nedeni; öngörülen eğitim programlarının yeterince tanitılmaması ve işgücü piyasasının ihtiyaçlarına dönük olmamasıdır. Son tahlilde kurumda hâlâ iş sağlığı ve güvenliği ile iş mevzuatı eğitimleri ön plandadır. Kısacası geçmiş dönemin izleri hâlâ kurumun eğitimlerinde gözlenebilir. Hâlbuki çalışma yaşamı iş sağlığı ve güvenliğinden ibaret değildir. Toplu görüşme ve sözleşme süreci, sendikal temsil, sosyal diyalog, yönetime katılma, düzgün iş, yıldırma (mobbing) vb. birçok konu başlığı bir ihtiyaç olarak beklemektedir. Eğitimlerin piyasanın talebi doğrultusunda belirleniyor oluşu bu konuda bir politikanın olmadığını göstermektedir.
$\mathrm{Bu}$ yapı hem işgücü piyasasının ihtiyaçlarına cevap verebilen bir potansiyel içermemekte hem de iş sağllğı ve güvenliği profesyonellerinin iş kazalarını azaltma yeteneğini üstün bir düzeye çıkarmamaktadır. Merkezden eğitim hizmeti satın alan birçok kuruluşun temel gayesi, iş teftişi esnasında bakanlığa bağlı bir kurumdan hizmet alındığının belgelenmek istenmesidir ${ }^{17}$. Ancak bu bakış açısının değiştirilmesi gerekmektedir. $\mathrm{Bu}$ değişime yol açabilecek en temel girişim ise Merkezin çalışma yönetimine uygun bir anlayış çerçevesinde yeniden örgütlenmesidir.

\footnotetext{
${ }^{17} \mathrm{Bu}$ tespitin temel dayanağ 1 gerçekleşen eğitimler esnasında eğitim talep edenlerin söylemleridir.
} 
Eğitim Konu Başlıklarındaki ve Programlardaki Değişim

$$
\text { Merkezin yürütmüş olduğu }
$$

faaliyetlerin dönemsel olarak akademik, teknokratik ve bürokratik bir anlayış çerçevesinde yürütüldüğünü belirtmiştik. Bu başlık altında bahse konu dönemler incelenmiştir ve bu anlayışların eğitim ve araştırma faaliyetlerini nasıl yönlendirdiği incelenmeye çalışılmıştır.

\section{5-1972 Yillari Arasinda Uygulanan Programlar (Akademik Dönem)}

$\begin{array}{crrr}\mathrm{Bu} & \text { yıllar } & \text { arasında } & \text { uygulanan } \\ \text { programlar } & \text { iki } & \text { dönem } & \text { altında }\end{array}$ değerlendirilmelidir. Birinci dönem; 1955-1960 yılları arası dönemdir. Bu dönemde ulusal ve yabancı bürokratlar sosyal politika anlayışı temelinde oluşturulan hizmet içi eğitim programlarına katılmışlardır. $\mathrm{Bu}$ dönemin sosyal ve iktisadi özellikleri YODÇE tarafından yürütülen eğitim faaliyetlerine de yansımıştır. 1945 yılında Çalışma Bakanlığı'nın, 1946 yılında İş ve İşçi Bulma Kurumu'nun kurulmasını (Makal, 2002: 203-216) müteakip çalışma yaşamıyla ilgili bürokrat bir kadro oluşmuştur. Bakanlık ile İ̈BK'nin kurulmasının hemen arkasından 1949 yılında UÇÖ tarafından hazırlanan teknik bir raporda da Türkiye'nin bu konularda duyduğu ihtiyaçlar tespit edilmiştir (Varlık, 1998). Öncelikli olarak sistemin işleyişinde rol alacak kadroların eğitilmesi bir gereklilik olarak ortaya çıkmış ve UÇÖ tarafından 1955 yılında kurulan Enstitünün 1955-1960 yılları arasındaki eğitim faaliyetleri iş teftişi ve iş güvenliği üzerine yoğunlaşmıştır. Eğitimlerin teknik yönü ağırlıklı olan konular arasından seçilmiş olduğu da bir başka tespittir. $\mathrm{Bu}$ durumun nedeni; Enstitünün kuruluşunu esas alan 13 Sayılı Ek Antlaşmanın içeriği ve Enstitüdeki uzmanlık birimlerinin iş sağlığı ve iş güvenliği üzerine odaklanmış bir şekilde tasarlanmış olmasıdır. Enstitü'nün 1960 yılında Türkiye Cumhuriyeti'ne devredilmesi ile birlikte bu durum değişmiştir.

İkinci dönem olan 1960-1972 yılları arası uygulanan programlar ise sendikacilık, toplu sözleşme, iş sağllğı ve güvenliği, verimlilik, beşeri sermaye gibi alanlarda uygulanan bir, üç ya da beş günlük bilimsel seminer programlarının yapıldığı dönemdir. Bu dönemde Enstitü'nün görev alanı 1961 Anayasa'sinda getirilen sosyal haklar ile artmıştır. 1960 yılını takip eden yıllarda, Türkiye'de önemli sosyal ve iktisadi gelişmeler elde edilmiş, ülkenin sanayi yapısı önemli ölçüde değişme sürecine girmiştir. $\mathrm{Bu}$ gelişmeye bağlı olarak, köyden kente göç hızlanmış, birinci göç hareketi 1950 yılı sonrasında, ikinci göç hareketi ise 1961 yılından başlayarak devam etmiş ve Türkiye'de işçi sayısında önemli bir artış gerçekleşmiştir. 1965 yılında Türkiye'de ücretlilerin sayısı üç milyon iken, bu sayı gittikçe artmış 1970'de dört milyon iki yüz bine, 1975 'de ise beş milyon dört yüz bine ulaşmıştır (Koç, 2003: 101). Türkiye'deki bu gelişmeler YODÇE'nin faaliyet alanının genişlemesine, müfredatına yeni konuların eklenmesine neden olmuştur. Tüm bu gelişmelerin sonucu, iş ve sosyal hayatla ilgili yeni kavramların, topluma ve çalışma hayatının taraflarına anlatılması ihtiyacını doğurmuştur (Cam, 2012). Birinci ve ikinci dönem arasındaki temel fark; birinci dönemde kamu çalışanlarına yönelik yetiştirme eğitimleri (hizmetiçi eğitimler) düzenlenirken ikinci dönemde kamu ve özel sektör temsilcilerinin katıldığı bilimsel seminerlerin düzenlenmiş olmasıdır. Eğitimler belli bir program dâhilinde yürütülmüş, seminerler ise günümüzdeki bildiri sunumuna benzeyen ve en uzunu beş gün süren bilimsel etkinlikler şeklinde gerçekleşmiştir (Cam, 2012: 84-102).

1960-1972 yılları arasındaki dönemin eğitim faaliyetleri arasında teknik konuların yanında sosyal politika konularının da geniş yer bulduğu görülebilir. Bu durumun temel iki nedeni vardır. Birincisi enstitü üzerinde İstanbul Üniversitesi İktisat Fakültesi Sosyal Siyaset Kürsüsünün etkisi ${ }^{18}$, diğer neden ise

18 1960-1972 yılları arasında bahse konu okulun birçok öğretim üyesi ek görevli olarak enstitüde çalışmıştır. Örnek olarak şu isimler gösterilebilir: Ord. Prof. Dr. Ferit Hakkı Saymen, Prof. Dr. Orhan Tuna, Doç. Dr. Sabahaddin Zaim, Doç. Dr. Nevzat Yalçıntaş, Doç. Dr. Nusret Ekin, Dr. Ekmel Zadil, Dr. Metin Kutal, Dr. Adnan H. Lavkan. Daha ayrıntılı açıklamalar için bakınız: Cam, 2012. 
1961 Anayasasının toplu sözleşme ve grev hakkını getirmiş olmasıdır. Her iki nedenin birlikte değerlendirilmesi ile eğitim programlarının seminerler dizisine dönüşmesi ve program içeriklerinin sosyal tartışma konularını kapsayacak şekilde değişmesiyle açılanabilir. Bu iki dönem arasındaki en önemli fark; konulardan ziyade eğitim tekniğinin değişmiş olmasıdır. Birinci dönem sınıf temelli ve düşük sayıda katılımcının yer aldığ1 görece uzun süreli programlardan oluşurken, ikinci dönemde eğitimler daha geniş sayıda katılımcının olduğu seminerler ve sonunda genel tartışmalar biçiminde sürdürülmüştür.

\section{5-2003 Yillari Arasinda Uygulanan Programlar ${ }^{19}$ (Teknokratik Dönem)}

Bu dönem, eğitimlerin ağırlıklı olarak iş müfettişlerinin kontrolü altında sürdürüldüğü dönemdir. Bu dönemdeki eğitimler genellikle günlük programlar şeklinde temel olarak iki başlık altında yürütülmüştür. Bu başlıklar; iş sağlığı ve güvenliği ile çalışma mevzuatıdır. $\mathrm{Bu}$ dönemin gerek ilk iki dönem gerekse bundan sonraki dönem ile olan temel farklarından biri; eğitim ve araştırma yayınlarının niceliksel olarak fazlalığıdır ${ }^{20}$. Bu dönemde sürdürülen eğitimlerde Merkezin herhangi bir belirleyiciliği olmamıştır çünkü eğitimler çoğunlukla İş Müfettişlerince yapılmıştır. Dolayısıyla bu dönemi İş Müfettişlerinin belirlemiş olduğu programların yürütüldüğü dönem olarak da tanımlayabiliriz.

\section{3-2013 Yillari Arasinda Uygulanan Programlar (Bürokratik Dönem)}

ÇSGB'nda 2003 yılında gerçekleştirilen yeniden yapılanma çalışmalarının kurum üzerinde ciddi bir etkisi olmuştur. Bu etki öncelikli olarak YODÇEM'in ÇASGEM'e dönüşmesi olarak kendini göstermiştir. Hem eğitim içerikleri hem de eğitim faaliyetinin kariyer meslek mensuplarınca verilebilmesini

19 1973-1985 yılları arasında üç çeviri dışında herhangi bir faaliyet yapılmadığı için başlıklandırmada doğrudan 1985-2003 yılları arası faaliyetlere geçilmiştir.

${ }^{20}$ Dönemler arası yayın sayıları için bakınız: Cam, 2012. sağlayan düzenlemeler getirilmiştir. ÇSGB'nca çıkartılan yasal mevzuat ${ }^{21}$ ile birlikte Merkezde İş Güvenliği Uzmanlığı, İşyeri Hekimliği ve İşyeri Hemşireliği programlarını uygulanmaya başlanmıştır. Sertifika eğitimlerinin yanında diğer eğitimlerin ücretli olarak verilmesi piyasa odaklı eğitim anlayışını doğurmuştur. Bu değişim Heyes'in (2001) belirttiği üzere çalışma yönetimi anlayışındaki değişimin sonucu olarak değerlendirilmelidir. Heyes, çalışma yönetimindeki bu değişimin Avrupa'nın birçok ülkesindeki Çalışma Bakanlıkları üzerindeki etkisini inceleyen çalışmasında, yeni kamu yönetimi anlayışı çerçevesinde özel sektör ile devletin bir arada çalı̧̧masının sonucu olarak değerlendirmektedir. $\mathrm{Bu}$ değişim dalgası Merkezin eğitim konu başlıklarında güncellemeye gidilmesine neden olmuştur. Fakat bu yenileme söz konusu yeni eğitim başlıkları için ciddi bir talep oluşturmamıştır. $\mathrm{Bu}$ bağlamda 1985-2003 yılları arasında uygulanan programların izleri bu dönemde de görülebilir. Merkez tarafından 2003-2013 yılında verilen eğitimlerin konu başlıkları; iş sağlığı ve güvenliği eğitimleri, iş ve sosyal güvenlik hukuku eğitimleri, ilk yardım eğitimleri, çalışma yaşamıyla ilgili diğer konu başlıkları olarak sıralanabilir. Bu eğitimler hem kurumsal hem de bireysel talep üzerine gerçekleştirilmektedir. Program başlıkları ağırlıklı olarak piyasaya dönük ve talep odaklı hazırlanmış başlıklar olmasına rağmen en çok talep gören başlıklar; sertifika programlarının yanında, temel düzey iş sağlığı ve güvenliği eğitimi, temel ilk yardım eğitimi, eğiticilerin eğitimi başlıklarıdır.

Ĕ̆itim Programlarının İşleyişi: Organizasyon, Uygulama ve Değerlendirme

Eğitimlerin organizasyonu 1955-1972 yılları ile 1985-2013 yılları arasında farklılık arz

${ }^{21}$ Bu konudaki ilk mevzuat: İşyeri Sağlık Birimleri ve İşyeri Hekimlerinin Görevleri ile Çalışma Usul ve Esasları Hakkında Yönetmelik, Resmî Gazete Tarihi: 16.12.2003, Sayısı: 25318 ve İş Güvenliği ile Görevli Mühendis veya Teknik Elemanların Görev, Yetki ve Sorumlulukları ile Çalışma Usul ve Esasları Hakkında Yönetmelik, Resmî Gazete Tarihi: 20.01.2004, Say1s1: 25352. 
etmektedir. Hem eğitim programlarının yapısındaki değişim hem de programların organizasyonu 1955-1972 yılları arasında bilimsel bir anlayış çerçevesinde yönetilirken, 1985-2013 yılları arasında bürokratik bir anlayışla yönetilmeye başlanmıştır. 1955-1972 yılları arasında asli ve tali görevler için ayrım yapılmıştır ve bu ayrım faaliyetlerin gerek içeriğinin belirlenmesinde gerekse eğitimcilerin seçiminde kendini göstermektedir. 1985-2003 ve 2003-2013 yılları arasında ise tali görev üstlenenlerin Merkez üzerindeki etkisi zaman içinde asli görevin önüne geçmiş ve teknokratik etki bürokratik bir mekanizmaya dönüşmüştür. Gerek Merkezin yönetişimci bir anlayış çerçevesinde faaliyet göstermeye başlaması gerekse organizasyon yapısındaki eksiklikler ve özellikle eğitimcilerin belirli ölçütler çerçevesinde belirlenmiyor oluşu çalışma ilişkileri alanında faaliyet gösteren Merkezin nitelik anlamında etkin ve verimli bir şekilde faaliyet göstermesine engel olan bir yapiya dönüşmesine yol açmıştır.

\section{Türkiye İçin Yeni Bir Model Önerisi: Temel İlkeler ${ }^{22}$}

Bu başlık altında Şekil 1 çerçevesinde analiz edilen eğitim ve araştırma sistemine uygun olarak hazırlanmış yeni bir organizasyon modeli önerisine ilişkin temel ilkeler sunulmuştur. Bu modelin özelliği Merkez yönetiminin sosyal taraf ve üniversitelerin ilgili bölümlerinin eşit temsil esasına dayalı bir yönetim yapısı ile olması gerektiğidir. Bunun sağlanabilmesi için siyasi karar mekanizmasının bu konuda adım atarak yeni bir yasal düzenleme yapması gereklidir. Modelde öngörülen diğer yenilik ise Merkezde yürütülecek eğitimlerin Türk işgücü piyasasının yapisına uygun olarak belirlenmesine olanak verecek bilimsel esaslara göre oluşturulmuş kurulları içermesidir. $\mathrm{Bu}$ metot ile hem eğitim konu başlıkları, fizibilite çalışmalarına dayalı olarak belirlenecek hem de Enstitüde verilecek eğitimler için belirlenecek

\footnotetext{
22 Önerilen modelde kullanılan kariyer meslek mensupları için önerilen unvanlar, TÜBİTAK ve Enstitülerinde kullanılan unvan adları temel alınarak geliştirilmiştir.
}

eğitimcilere standart getirilecektir. Modelin en önemli özelliği ise yöneticilerin belirli niteliğe sahip kişilerden oluşmasıdır. ÇASGEM'in bir eğitim ve araştırma merkezi olduğu düşünüldüğünde, yarı akademik ve yarı bürokratik özellikler içeren bu kurumun yönetiminin de bu özelliklere uygun yöneticilerce yönetilmesi Merkezin kuruluş felsefesine uygun olacaktır. Hizmet örgütlenmesinin yukarıda belirtilen şekilde yapılması Enstitünün bilgi üretilmesi için gerekli yapıyı ifade etmektedir.

Modelde öngörülen diğer önemli yenilik, eğitim ve araştırma bölümlerinin, eğitime katılacak kişi ya da grupların statülerine göre belirlenmiş olmasının gerekliliğidir. Örneğin sendikacı eğitimi, işçi eğitimi ve kamu personeli eğitimi farklı şekillerde tasarlanması gerekli eğitimlerdir (UÇÖ, 1993: 91). Çünkü, bahse konu hedef kitlelerin gerek çalışma şartları farklı hukuki mevzuat hükümlerine göre düzenlenmiştir gerekse çalışma yaşamında ve üretim sürecinde üstlendikleri rol ve görevler farklıdır.

Önerilen modele göre Enstitü üç ana bölümden oluşmalıdır. Bunlar; Enstitü Bilim Kurulu, Uzmanlık Bölümleri ve İdari Bölümlerdir. Enstitü Bilim Kurulu en üst karar organıdır ve temel görevi; Enstitünün faaliyetlerine ilişkin yıllık programlar dahilinde karar almak ve Enstitü yönetimini bir süre için belirlemektir.

\section{Enstitünün Görevleri}

Enstitünün görevleri dört ana başlıktan oluşmaktadır. Bunlar; eğitim faaliyetleri, araştırma faaliyetleri, yayın faaliyetleri ve proje faaliyetleridir. Etkinlik konuları; çalışma normları; çalışma koşulları, ücretler, istihdam koşulları, iş sağlığı ve güvenliği, çalışma ortamı, sosyal güvenlik, iş teftişi, ulusal istihdam politikası, işsizlik sigortası, mesleki eğitim, mesleki yönlendirme, istihdam hizmetleri; işverenlere ve işçilere yönelik hizmetler, toplu pazarlık ve toplu uyuşmazlıkların çözümü, sosyal güvenlik ve sosyal hizmet alanlarından oluşmaktadır. Bu konular üzerine aşağıdaki satırlarda tanımlanan uzmanlık bölümleri aracılığıyla çalışılır. 


\section{Enstitï Teşkilâtı}

Bir yetişkin eğitim merkezi olarak tasarlanmış kurumun, Enstitü olarak yapılandırılması ve mevcut eğitim programlarının gözden geçirilmesi buna ek olarak üniversiteler ile işbirliği içinde lisansüstü programların uygulanması gerekmektedir. Bu konuda Merkezin kuruluş yıllarında aynı politikanın ürünü olarak (Çeçen, 2001) kurulmuş olan Türkiye Orta Doğu ve Amme İdaresi Enstitüsü'nde (TODAİE) Enstitü için önerilen uygulamalar başarıyla sürdürülmektedir. Ancak Enstitünün çalışma yaşamıyla ilgili eğitim ve araştırma programları sürdüreceği dikkate alındığında, organizasyonun çalışma yaşamının üçlü yapısına uygun bir şekilde tasarlanması gerekir. Bunun için yapılması gerekli olan en önemli değişiklik; çalışma yönetiminin temel amaçlarından biri olan üçlü yapıya dayalı bir kurul oluşturmaktır. Bu durumda hem Enstitü için getirilen eleştirilerin önüne geçilebilir hem de Enstitü sadece siyasetin ve bürokrasinin öngördüğü yönetim anlayışının dışında çalışma yaşamının aktörleri tarafından yönetilen bir kurum haline gelebilir. Sosyal tarafların kurul üyesi olarak yönetimde söz sahibi olmaları, kurumun yönetimine sürekli müdahale edebilecekleri anlamını taşımamalı sadece karar alma süreçlerinde fikirlerine başvurulan bir ortak akıl ve diyalog platformu oluşturmayı amaçlamalıdır. $\mathrm{Bu}$ bağlamda Enstitü için önerilen organizasyon modelinin temel bileşenleri şunlardır;

\section{Enstitü Yönetimi}

Enstitünün yönetimi; Enstitü Bilim Kurulu (EBK), Enstitü Genel Müdürü (EGM) ile Müdür Yardımcılarından oluşur.

\section{Enstitü Bilim Kurulu}

Kurul üyeleri; Türkiye'de etkinlik gösteren işçi, işveren ve memur konfederasyon ya da sendikalarının yönetici ya da uzman düzeyindeki temsilcilerinden, en çok üyeye sahip ilk üç bağımsız sendikal kuruluş temsilcilerinden, üniversitelerin alanında en az doçentlik derecesine sahip; çalışma ekonomisi ve endüstri ilişkileri, iş hukuku, halk sağlığ1 anabilim dalı altında iş sağlığı ve güvenliği alanında uzmanlaşmış öğretim üyelerinden, TÜBİTAK'tan, TÜBA'dan, mesleki kuruluşların önerecekleri ve Enstitünün etkinlik alanıyla ilgili okullardan mezun, varsa doktora yoksa en az yüksek lisans derecesine sahip uzmanlardan ve Enstitüde görev yapan sosyal ve teknik kökenli başuzman araştırıcılardan oluşur. EBK üyelerinin seçiminde aranacak nitelikler ve ayrıntılar Enstitü tarafından çıkartılacak bir yönetmelik ile belirlenir.

\section{Enstitüsü Genel Müdürü ve Müdür Yardımcıları}

EGM, Enstitü Bilim Kurulu tarafından kıdemli başuzman araştırıcılar arasından seçimle en az üç yıllığı̆na seçilmelidir. Üç yıllık etkinlik dönemini başarılı bir şekilde geçiren yönetici tekrar üç yılı̆̆ına seçilebilir. EGM'nin en az doktora derecesine sahip olması, iyi düzeyde İngilizce bilmesi ve bunu Türkiye'de ÖSYM tarafından yapılan ya da buna eşdeğer olduğu YÖK tarafından kabul edilen diğer uluslararası sinavlardan birinden $\% \quad 70$ oranında başarılı olduğunu gösteren ve son beş yıl içinde alınmış bir belgeyle kanıtlaması gerekmektedir. Aynı şartları taşıyan iki müdür yardımcısı da EBK tarafından aynı seçim yolu ile belirlenir. Müdür yardımcısı olabilmek için en az uzman araştırıcı olmak gereklidir. Ayrıca üniversitelerin çalışma hayatıyla ilgili bölümlerinden mezun olmak ve lisansüstü eğitimini de çalışma yaşamıyla ilgili disiplinlerarası bir konuda yapmış olmak zorunludur. Bu bölümlerin ve disiplinlerarası konuların ne olduğuna ilişkin ayrıntılar EBK üyesi akademisyenlerce ya da oluşturulacak bilimsel bir çalışma grubu ile belirlenir. Ayrıntılar bir yönetmelik ile düzenlenir.

\section{Uzmanlık Bölümleri}

Enstitüde aşağıda belirtilen uzmanlık bölümleri oluşturulmalıdır. Bölümler oluşturulurken dikkate alınması gerekli olan temel nokta; her bölümün çalışma alanı ile ilgili olan kamu kurum ve kuruluşları ile üniversitelerin ilgili bölümlerinde çalışan öğretim üyeleri ile birlikte çalışmalarıdır. Her bölümün, Enstitü asli personeli ile birlikte ayrıntıları aşağıda belirtilen kurum, kuruluş ve ilgili öğretim üyelerinden oluşan bir uzmanlık bölüm kurulu olmalı, her yıl ocak ayında ya da 
yaz dönemi sonrasında ilgili bölümün yapacağı çalışmalar bölüm kurulunun alacağ doğrultusunda belirlenmelidir. Bu şekilde ülke ihtiyaçları ve ilgili alana ilişkin sorunlarının tespit edilebilmesi ile birlikte hem mevzuat hem de uygulamacılar için sorunların çözümüne yardımcı olabilecek politika belgelerinin oluşturulması sağlanabilir. Uzmanlık bölümlerinin görev alanına ilişkin yıllık bilimsel raporlar ve araştırma sonuçları ile benzeri çıktıları, etkinlik dönemi sonunda tek bir politika belgesine dönüştürülerek Türkiye'nin çalışma hayatına ilişkin misyon belgesi oluşturulur. ÇSGB bağlı ve ilgili kuruluşlarının hazırlanan belge çerçevesinde çalışmalarını gerçekleştirmeleri ve yıllık sonuç raporlarını Enstitüye göndermeleri ÇSGB Teşkilât Kanununda yapılacak bir değişiklik ile yasal zorunluluk haline getirilir.

İş ve Sosyal Güvenlik Hukuku Bölümü: İş mevzuatına yönelik çalışmalar (Sosyal Güvenlik Kurumu, Çalışma Genel Müdürlüğü, İş Teftiş Kurulu ve Üniversitelerin ilgili bölümleri ile kurumsal bağlantı)

İşgücü Piyasası ve İstihdam Bölümü: İşsizlik sorunu ve istihdam politikalarına yönelik çalışmalar (Türkiye İş Kurumu, İş Teftiş Kurulu, Çalışma Genel Müdürlüğü, Kalkınma Bakanlığı ve Üniversitelerin ilgili bölümleri ile kurumsal bağlantı)

Gelir Dağılımı ve Gelirler Politikası Bölümü: Gelir dağılımında adaletsizlik ve gelir dağılımının düzeltilmesine yönelik politika çalışmaları (TUİK, Maliye Bakanlığı, Ekonomi Bakanlığı, Kalkınma Bakanlığı ve Üniversitelerin ilgili bölümleri ile kurumsal bağlantı)

Sosyal Diyalog ve Çalışma İlişkileri Bölümü: Sendikacılık, toplu ve bireysel iş ilişkileri, insan kaynakları yönetimi çalışmaları (Çalışma Genel Müdürlüğü, İşçi ve İşveren Konfederasyonları, Farklı İş Kollarında İşçi ve İşveren Sendikaları, TÜSIAD, TOBB, TESK ve Üniversitelerin ilgili bölümleri ile kurumsal bağlantı)

Sosyal Hizmet Bölümü: Sosyal Dişlanma, sosyal içerme, sosyal çalışma, aile, yaşli, çocuk ve özürlülere yönelik çalışmalar (Aile ve Sosyal
Politikalar Bakanlığı ve Üniversitelerin ilgili bölümleri ile kurumsal bağlantı)

Yurtdışı İşçi Sorunları ve Sosyal Güvenlik Bölümü (DIYIIH, SGK, Dışişleri Bakanlığı ve Üniversitelerin ilgili bölümleri ile kurumsal bağlantı)

İş Sağlı̆̆ı Bölümü̈: (İş Teftiş Kurulu, SGK Teftiş Kurulu, Sağlık Bakanlığı, İSGGM, TTB, Hıfsısıhha Enstitüsü, Fişek Enstitüsü ve Üniversitelerin ilgili bölümleri ile kurumsal bağlantı)

İş Güvenliği Bölümü: (İş Teftiş Kurulu, SGK Teftiş Kurulu, İSGGM, TMMO ve Üniversitelerin ilgili bölümleri ile kurumsal bağlantı)

İstatistik Bölümü: (Çalışma Genel Müdürlüğü, DIYYİH, İSGGM, İş Teftiş Kurulu, SGK Teftiş Kurulu, İŞKUR, TUIK ve Üniversitelerin İlgili Bölümleri ile kurumsal bağlantı)

Proje Yönetimi Bölümü: Enstitüde yürütülecek ulusal ve uluslararası kaynaklı tüm projelerin idari açıdan yönetilmesi ile ilgili bölümdür, projenin yönetilmesi ve içeriklerine yönelik uzmanlık gerektiren konular bölüm uzmanları tarafından yürütülür.

Dış IIlişkiler Bölümü: Enstitünün yabancı ülke kurumları ile ilgili işlerini ve işbirliğini, gerekli yazışma ve onayları yürüten bölümdür.

\section{Ĕ̈itim ve Araştırma Kurulları}

Hedef Kitleye Yönelik Eğitim Planlama Kurulları

Çalışanlara yönelik eğitimler, sendikacılara yönelik eğitimler, kamu personeline yönelik eğitimler, işverenlere yönelik eğitimlerin planlandiğı kuruldur

Araştırma Kurulları

Ulusal ve Uluslararası araştırma projelerinin planlandığı kuruldur. 
Proje Kurullart ${ }^{23}$

AB Kaynaklı Projeler, MATRA Projeleri, Diğer Fon Kaynaklı Projelerin planlandı $\breve{g} 1$ kuruldur.

Kütüphane ve Doküman Kurulları

Bilimsel Dergi Kurulu: Çıkartılacak hakemli dergiye ilişkin kararları alır.

Diğer Bilimsel Yayınlar Kurulu: Kitap, ansiklopedi, teknik terimler sözlüğü vb. yayınlara ilişkin kararları alır.

Diğer Yayınlar Kurulu: Yıllık, Bülten vb. yayınlara ilişkin kararları alır.

Tanıtım Yayınları Kurulu: Broşür, kitapçık, ilan, afiş, poster vb. yayın ve tanıtım malzemesine ilişkin kararları alır.

\section{Asli personel: Araştıricılar}

Her birime EBK tarafından belirlenecek ve yeterli sayıda Kıdemli Başuzman Araştırıcı, Başuzman Araştırıcı, Uzman Araştırıcı, Araştırıcı ve Araştırıcı Yardımcısı kadroları ihdas edilir. $\mathrm{Bu}$ kişiler mezun oldukları üniversite bölümleri ve lisansüstü eğitimlerine göre belirtilen bölümlerde görevlendirilirler. Uzman araştırıcılığa atanabilmek için tezli yüksek lisans, başuzman araştırıcıllğa atanabilmek için doktora ve kıdemli başuzman araştırıcılığa atanabilmek için doçentlik belgesine sahip olmak zorunludur. Ayrıca söz konusu her unvana atanabilmek için belirtilen belgelere ek olarak yapılması gerekli ulusal ve uluslararası yayınlar ve diğer faaliyetlere ilişkin ayrıntılar EBK kararı ile tespit edilecek bir akademik alt kurul tarafından karara bağlanır. Bu karar her yıl ülkenin bilim politikasına göre yenilenebilir. Araştırıcıların istihdamına ilişkin sınav ve diğer ilkeler EBK tarafından tüzük olarak hazırlanır ve Bakanlar Kurulu onayına sunulur.

\section{Diğer personel}

Bu konudaki ayrıntılar ülkedeki benzeri uygulamalara göre düzenlenir. Bu personel İş

23 Türkiye'nin $\mathrm{AB}^{\prime}$ ye adaylık sürecindeki mevcut yapıya göre belirlenmiştir. Yapı değişikliği durumunda kurullarda Enstitü Kararıyla değiştirilir.
Kanununa tabi olarak sözleşmeli çalıştırılır ve performansa dayalı ücret sistemine göre belirlenmiş nesnel ölçütlere göre ücret alır.

\section{Değerlendirme ve Sonuç}

Türkiye'de yetişkinlere yönelik sosyal politika eğitimlerinin uzmanlık bölümlerine göre organize olmamış bir şekilde yürütülmesi, farklı kuruluşların mevzuatındaki görev çatışmaları ve kurumlar arası rekabet, çalışma yaşamında eğitim ve araştırma faaliyetlerine ilişkin yeni bir düzenleme ihtiyacını doğurmuştur. Bu ihtiyaç 2003 yılında Yakın ve Orta Doğu Çalışma Eğitim Merkezi kuruluş yasasının değiştirilmesine ilişkin hukuki düzenleme ile giderilmesi gerekli iken sadece kurum adının ve birkaç maddenin değiştirilmiş olması ve kurumda çalışma ve sosyal güvenlik eğitim uzman yardımcısı istihdamını öngören bir maddenin eklenmesi ile sınırlı kalmıştır.

Çalışma yaşamıyla ilgili eğitim ve araştırma faaliyetlerinin etkin ve amaca yönelik bir şekilde yürütülmesinin ön şartı; kuruluş yasasında belirtilen görevleri yerine getirebilecek sistemli bir örgütlenmenin varlığıdır. Konu mevzuat açısından incelendiğinde, Merkezin organizasyonu 1960 yılında çıkartılan 7460 Sayılı Kuruluş Yasası ve ilgili yönetmelikler ile düzenlenmiştir. Gerek kuruluş yasası gerekse yönetmelikler mevcut yapının daha iyi işlemesi önünde birer engel teşkil etmektedir. Çünkü kuruluşundan günümüze Merkez gerek coğrafi gerekse etkinlik alanı itibariyle farklı süreçlerden geçmiş ancak söz konusu kuruluş yasası ve yönetmeliklerde gerekli değişiklik bu değişime paralel bir şekilde yapılamamıştır. Bu bağlamda bir değerlendirme yapıldığı zaman kurumunun yönetimi de bu sinırlılıklar içinde hareket etmek zorunda kalmıştır (ÇASGEM, 2009). Öncelikle belirtilmesi gereken kuruluş yasasının elli üç yıl önce yasalaşmış ve şimdiye kadar üzerinde ciddi bir değişikliğin gerçekleşmemiş olmasıdır. Yarı akademik yarı bürokratik bir özelliğe sahip olan Merkezin faaliyetleri bilimsellikten uzaklaşmıştır.

1960 yılından bugüne kadar geçen elli üç yılda yasada birkaç küçük değişiklik 
yapılmıştır ${ }^{24}$. Bu özellikleriyle Yasa eskimiştir ve güncel gereksinimleri karşılamamaktadır ${ }^{25}$. $\mathrm{Bu}$ tespit yasanın değişiklik gerekçesinde de belirtilmiş olmasına rağmen sistemi kökten yenileyecek bir değişiklik önerisi de sunulmamıştır. Bu durum, kurumu eğitim alanında arz ve talebi buluşturan bir aracı kuruma dönüştürerek etkili çalışmasını engellemiştir. Asıl görevi araştırma yapmak, istatistik oluşturmak ve eğitim düzenlemek olan kurumda bu görevlerin yapilmasını engelleyen pek çok organizasyonel sorun varlığını sürdürmüştür. Bu sorunların başında kurumun hizmet örgütlenmesinin nasıl yapılması gerektiğinin bilinmemesi gelmektedir. Örneğin bu merkez, ÇSGB'nın bir bağlı kuruluşu gibi değil, bir hizmet birimi gibi çalışmaktadır. Pek çok iş yapılırken, mevzuat gerektirmediği halde ÇSGB'ndan onay alınmaktadır. Merkez yönetiminin doğrudan siyasi otorite tarafından belirlenmesi bu sonuca yol açmaktadır. Kurumun kendi kendine karar alamıyor olması yönetim içinde yönetim yaratmaktadır. Bu sorun; kurum yönetimi için kuruluş amacına uygun niteliğe sahip yöneticilerin göreve getirilmeleri ve belirli bir süre görevi üstlenebilmelerine olanak sağlayacak bir yasal düzenlemenin gerçekleşmesi ile çözülebiliir ${ }^{26}$. Aksi halde kurum kişisel çabalar ve iyi niyet temelinde yapılacak işler ile sınırlanacaktır. Ancak günümüz dünyasında eğitim ve araştırma görevi üstlenmiş kuruluşların görevleri iyi niyet ile sürdürülebilecek nitelikte değildir. Özellikle gerek eğitim konuları ve eğitimcilerin seçimi gerekse araştırma konularında standartların olması gerekmektedir.

Merkezin yönetim, ana hizmet ve yardımcı hizmet birimlerinin yeniden tanımlanması bir gereklilikten ziyade

$24 \mathrm{Bu}$ değişiklikler şunlardır: Eğitim Uzman Yardımcısı istihdamı ile ilgili değişiklik vd.

${ }^{25} \mathrm{Bu}$ değişiklik gerekçesi bu çalışmadaki 11 numaralı dipnotta açıklanmıştır.

${ }^{26}$ Örneğin Rektörlerin ve Dekanların belirli görev süreleri bulunmaktadır. Aynı şekilde Türkiye Orta Doğu ve Amme İdaresi Enstitüsü Genel Müdürü için de benzeri bir düzenleme getirilmiştir. Bu şekilde belirli sürelerle görev yapabilme imkânı yönetime istikrar getirmektedir. zorunluluk olarak ortaya çıkmaktadır. Yönetim nasıl olmalıdır? Çalışma yaşamının üçlü yapıya sahip olan özelliği konuyla ilgili eğitim ve araştırma faaliyeti yürütecek bir merkezin ya da enstitünün de bu yap1 ile paralel olan bir şekilde örgütlenmesini gerektirir ${ }^{27}$. Bu anlamda sosyal taraflar ile yönetsel birlik olmalıdır. Eğer politika belirleyiciler devletin gücünün baskın olduğu bir örgüt modelini benimsemiş iseler bu durumda da sosyal taraflarla hizmet örgütlenmesi içinde işbirliği yapmaları bir gerekliliktir çünkü çalışma ilişkileri üçayaklı bir yapıdan oluşmaktadır. Kural koyucu ve düzenleyici olma özelliği ile devletin yanında birbirleri ile yakın etkileşim içinde olan işçi ve işveren tarafları bu üçlü yapının birer ayağını oluşturmaktadırlar.

Sosyal taraflarla yönetsel ya da hizmet çerçevesinde sürdürülecek işbirliği Enstitünün etkin bir şekilde çalışabilmesi için gerekli fakat yeterli değildir. Enstitüde görev alacak kişilerin de belirli güvence statülerine sahip olmaları gereklidir. Çünkü bu tip bir kuruluşun tüm hizmet alanları bilimsel faaliyetlerden oluşmaktadır. Farklı siyasal arka plana sahip hükümetlerin çalışma yaşamıyla ilgili farklı siyasi kararları olabilir. Merkezde yapılan eğitimler ve araştırma sonuçları hükümet politikalarını eleştirebilir ya da destekleyebilir. $\mathrm{Bu}$ durumda uzman personelin bilimsel özgürlük ilkelerine uygun şekilde davranabilmeleri önemlidir. Bunun için yapılması gereken; uzmanlık gerektiren işleri yapan nitelikli personelin yasalar ile güvence altına alınması ve özerk bir yapının kurulmasıdır.

$\mathrm{Bu}$ nedenle çalışma yaşamıyla ilgili eğitim ve araştırma faaliyetlerinin yönetimi ve sosyal politikanın kesiştiği noktanın temel çıktısı; bu eğitimlerin yönetiminin sosyal politika formasyonuna sahip bir anlayış çerçevesinde sürdürülmesinin gerekliliğidir. Bunun temelinde olan iki etkinlik ise araştırma ve eğitimdir. Bu etkinlikler ne kadar örgütlü ve

27150 Sayılı Çalışma Yönetimi Sözleşmesi'nde de çalışma yönetimiyle ilgili kuruluşların üçlü yapı üzerinde şekillenen bir anlayış çerçevesinde yönetilmeleri gerektiği belirtilmektedir. 
eşgüdüm içinde yapılırsa, hedeflenen kitle için yapılan eğitim faaliyetleri de amaca uygun bir şekilde gerçekleşmiş olur ayrıca söz konusu ülkenin çalışma hayatını belirleyen politikalar için nitelikli veri üretilir. $\mathrm{Bu}$ veri üretim sürecinin politika belirleyiciler için kaynak oluşturması ise üretilen verinin uygulanabilirliği ile orantılıdır. Bunun için yapılması gereken; eğitim faaliyetlerinin organizasyonunun yukarıda tanımlanan nitelikte bir yapı çerçevesinde örgütlenmesi, araştırma faaliyetlerinin ise önceden planlanmış amaçlara yönelik ve birbirini tamamlayıcı nitelikte olmasıdır. Bu yapı icracı birimler ile kaynak üreten birimlerin eklektik bir şekilde yapılandırılması ile oluşturulabilir. Bu şekilde Bakanlığın tüm birimlerinin faaliyetlerine ilişkin üretilen ham bilgi, Enstitü tarafından belli bir sistematik içinde toplanmalı, bilimsel ölçülere göre işlenmeli ve yayınlanmalıdır. Söz konusu yayınlar ise nihai olarak merkez tarafından yürütülen eğitimler için bir kaynak olarak çalışma yaşamının temel sorunlarının çözümünde rol alan aktörlere aktarılmalıdır.

\section{Kaynakça}

Akan, Taner (2011) "Sosyoloji, Politika ve Ekonomi [SPE]' Bölümüne Doğru: Çalışma Ekonomisi ve Endüstri İlişkileri Bölümlerinin Yeniden Yapılanmasına İlişkin Bir Model Önerisi", "İş,Güç" Endüstri İlişkileri ve İnsan Kaynakları Dergisi, Cilt: 13, Say1: 3, 27-48.

Aktay, Nizamettin (2000) Toplu İş Sözleşmesi, Ankara.

Altan, Ömer Zühtü (2006) Sosyal Politika Dersleri, No: 1952, Eskişehir: Anadolu Üniversitesi Yayınları.

Cam, Erdem (2012) ÇASGEM Tarihi 1955 - 2011 Türkiye'de Sosyal Politika - İş Sağlığı Güvenliği Eğitimleri, Yayın No: 34, Ankara: Çalışma ve Sosyal Güvenlik Eğitim ve Araştırma Merkezi Yayınları.

Çalışma ve Sosyal Güvenlik Eğitim ve Araştırma Merkezi (ÇASGEM) (2009) Ön Inceleme Raporu - ÇASGEM'in Konum ve Rolü: Değerlendirme ve Görüşler, Çalışma Grubu: Halis Yunus Ersöz, Ahmet Cevat Acar, Sedat Murat, Nihat Erdoğmuş, Tekin Akgeyik, Süleyman Özdemir, Yayınlanmamış Rapor, Ankara, 19 Ağustos 2009, ÇASGEM.

Çeçen, Anıl (2001) “Türkiye'nin Gelecek Yirmi Yı11”, ODTÜ Mezunlar Derneği'nde Yaptı̆̆̆ Konuş̧ma (Derleyen: Nermin Fenmen), 24 Kasım 2001, Ankara.

[http://www.odtumd.org.tr/calismagr/yayin/b ulten/104/soylesi.htm] (26.12.2005)

Çiner, Can Umut (2007) “Türkiye'de Çalışma Yönetiminin Dönüşümü: İstihdamin Yönetimindeki Dönüşüm", Cahit Talas Anısına Güncel Sosyal Politika Tartışmaları, Yayına Hazırlayan: Berrin Ceylan Ataman, Ankara Üniversitesi Siyasal Bilgiler Fakültesi, Sosyal Politika Araştırma ve Uygulama Merkezi, Yayın No: 595, 259-284.

Ekmekçi, Ömer (2009) İşyeri ve Ortak Sağlık Güvenlik Birimleri Mevzuatı Açısından İșveren Yükümlülükleri Semineri, İstanbul, 17 Aralık 2009, Ankara: TísK.

Heintz, James ve Francie Lund (2012) “Welfare Regimes and Social Policy, A Review of the Role of Labour and Employment", Gender and Development Programme, United Nations Research Institute for Social Development, Paper Number 17.

Hesapçıŏlu, Muhsin (1994) Insan Kaynakları Yönetimi ve Ekonomisi, İstanbul: Beta. 
Heyes, Jason (2011) Labour Ministries and Labour Amnistration in Transition: Recent Developments and Future Prospects, Working Document No: 16, Geneva: International Labour Office.

Husband, J.I. (1980) Labour Administration A General Introduction, Genava: International Labour Office.

International Labour Organization (ILO) (1961) ILO Report on the Institute of Labour Administration for the Near and Middle East Istanbul 1955-1959, A Regional Experiment in the Training of Labour Administration Officials, International Labour Office, Labour Administration and Inspection Programme, Geneva: International Labour Organization.

International Labour Organization (ILO) (1967) Meeting of Heads of Official Services for Occupational Safety and Health, Official Services for Occupational Safety and Health, Geneva, 20-29 November 1967.

International Labour Organization (ILO) (2011) Report V, Labour Administration and Labour Inspection, International Labour Conference, 100th Session, Geneva: International Labour Organization .

Işıklı, Alpaslan (2003) Gerçek Örgütlenme Sendikacılık, Ankara: İmge Kitabevi.

Japan Institute for Labour Policy and Training (JILPT) (2011)

[http://www.jil.go.jp/english/organization/abo utus.htm] (25.10.2011)

Koç, Yıldırım (2003) Türkiye'de İşçi Sınıfi ve Sendikacılık Hareketi Tarihi, Ankara: Yol-İş Yayınları.

Koçer, Melih (1963) 1962 Yılında Yakın ve Orta Doğu Çalışma Enstitüsü, İstanbul.

Koray, Meryem (2000) Sosyal Politika, Bursa: Ezgi Kitabevi Yayınları.

Makal, Ahmet (2002) Türkiye'de Çok Partili Dönemde Çalışma İlişkileri: 1946 - 1963, Ankara: İmge Kitabevi Yayınları.

Uluslararası Çalışma Örgütü (UÇÖ) (1978a) C150 Labour Administration Convention, [http://www.ilo.org/ilolex/english/subjlst.htm] (19.06.2011)

Uluslararası Çalışma Örgütü (UÇÖ) (1978b) 158 Labour Administration Recommendation, [http://www.ilo.org/ilolex/english/subjlst.htm] (19.06.2011)
Uluslararası Çalışma Örgütü (UÇÖ) (1993) İşçi Sendikaları ve ILO İşçi Eğitimi El Kitabı, (Çev.: Türk-İş) Cenevre: Uluslararası Çalışma Bürosu.

Piyal, Bülent (2005) “Çalışma Yönetiminde Araştırma ve Eğitim", Yayınlanmamış Makale.

Piyal, Bülent (2009) İş Sağlığı ve Güvenliğinde Türkiye'nin Avrupa Birliğine Uyum Sorunu, Ankara: Belediye İş Sendikası AB'ye Uyum Dizisi

Research Institute for Labour and Social Affairs (RILSA) (2011)

[http://www.vupsv.cz/index.php?p=index\&sit $\mathrm{e}=\mathrm{en}](17.08 .2011)$

Talas, Cahit (1959) “Milletlerarası Çalışma Teşkilatı ve Türkiye (27 Yıllık İşbirliği)", Çalışma Dergisi, Cilt.1, Sayı:3, Kasım - Aralık 1959.

Talas, Cahit (1990) Toplumsal Politika (Giriş), Ankara: İmge Kitabevi.

The Institute of Labour and Social Research (LSRC) (2011) [http://www.dsti.lt/about_inst.html] (10.08.2011)

Tuna, Orhan ve Nevzat Yalçıntaş (1999) Sosyal Siyaset, İstanbul: Filiz Kitabevi.

Turan, Kâmil (1979) Milletlerarası Sendikal Hareketler, Ankara: A.İ.T.I.A. Yayınları.

Türkiye Büyük Millet Meclisi (1952) Milletlerarası Çalışma Bürosu ile Türkiye Cumhuriyeti Hükümeti arasında İstanbul'da Yakın ve Orta Doğu İş Gücü Faaliyet Merkezi kurulması için Cenevre'de imzalanan Anlaşmanin onanması hakkında 5947 sayıl Kanun, Resmi Gazete Tarihi: 06 Haziran 1952, Sayısi: 8134.

Türkiye Büyük Millet Meclisi (1953) 6114 Sayılı Yasa, Kabul Tarihi: 03 Temmuz 1953. Resmî Gazete Tarihi: 10 Temmuz 1953, Sayısı: 8454.

Türkiye Büyük Millet Meclisi (1960) Zabıt Ceridesi, Sabık Zabıt Hulâsası, Kırkıncı İnikat, 18.II.1960 Perşembe, Devre: XI, Cilt: 11, İçtîma: 3, Birinci Celse.

Türkiye Büyük Millet Meclisi (1960) Zabıt Ceridesi, Sabık Zabıt Hulâsası, Ellinci İnikat, 28.II.1960 Pazar, Devre: XI, Cilt: 12, İçtîma:3, Üçüncü Celse.

Türkiye Büyük Millet Meclisi (TBMM) (1983) Çalışma ve Sosyal Güvelik Bakanlı̆̆g'nın Teşkilât ve Görevleri Hakkında 184 sayılı Kanun Hükmündeki Kararname, Resmî Gazete Tarihi: 14 Aralık 1983. 
Türkiye Büyük Millet Meclisi (TBMM) (1985) Çalışma ve Sosyal Güvenlik Bakanliğının Teşkilât ve Görevleri Hakkında Kanun Hükmünde Kararname ve Çalışma ve Sosyal Güvenlik Bakanlığının Teşkilât ve Görevleri Hakkında 184 Sayılı Kanun Hükmünde Kararnamenin Bazı Hükümlerinin Değiştirilmesi Hakkında Kanun Hükmünde Kararnamenin Değisştirilerek Kabulü Hakkında Kanun, Resmî Gazete Tarihi: 18.1.1985 Sayısı: 18639.

Türkiye Büyük Millet Meclisi (TBMM) (2003) Sosyal Güvenlik Kurumu Teşkilâtının Kurulması ile Bazı Kanun ve Kanun Hükmünde Kararnamelerde Değişiklik Yapılması Hakkında Kanun Teklifi ile Gerekçesi.

V.V. Giri National Labour Institute (VVGNLI) (2011) [http://www.vvgnli.org] (15.07.2011)

Varlık, M. Bülent (1998) "Milletlerarası Çalışma Bürosunun Türkiye Raporu-1949", Türkiye Sendikacılık Ansiklopedisi, Cilt: 3, (İstanbul: Türkiye Ekonomik ve Toplumsal Tarih Vakfi). 